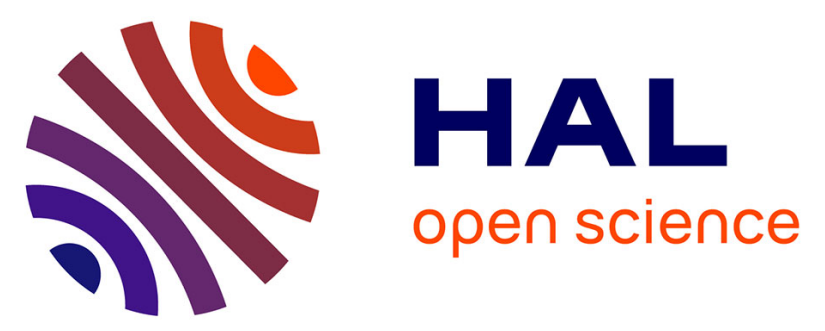

\title{
O3-NaxMn1/3Fe2/3O2 as a positive electrode material for Na-ion batteries: structural evolutions and redox mechanisms upon $\mathrm{Na}+($ de)intercalation
}

Benoit Mortemard de Boisse, Ju-Hsiang Cheng, Dany Carlier-Larregaray, Marie Guignard, Chun-Jern Pan, Sylvie Bourdineaud-Bordère, Dmitry A. Filimonov, Christina Drathen, Emmanuelle Suard, Bing-Joe Hwang, et al.

\section{To cite this version:}

Benoit Mortemard de Boisse, Ju-Hsiang Cheng, Dany Carlier-Larregaray, Marie Guignard, Chun-Jern Pan, et al.. O3-NaxMn1/3Fe2/3O2 as a positive electrode material for Na-ion batteries: structural evolutions and redox mechanisms upon $\mathrm{Na}+$ (de)intercalation. Journal of Materials Chemistry A, 2015, 3 (20), pp.10976-10989. 10.1039/c4ta06688j . hal-01166294

\author{
HAL Id: hal-01166294 \\ https://hal.science/hal-01166294
}

Submitted on 12 Feb 2021

HAL is a multi-disciplinary open access archive for the deposit and dissemination of scientific research documents, whether they are published or not. The documents may come from teaching and research institutions in France or abroad, or from public or private research centers.
L'archive ouverte pluridisciplinaire HAL, est destinée au dépôt et à la diffusion de documents scientifiques de niveau recherche, publiés ou non, émanant des établissements d'enseignement et de recherche français ou étrangers, des laboratoires publics ou privés. 


\section{ARTICLE}

\section{Table of contents}

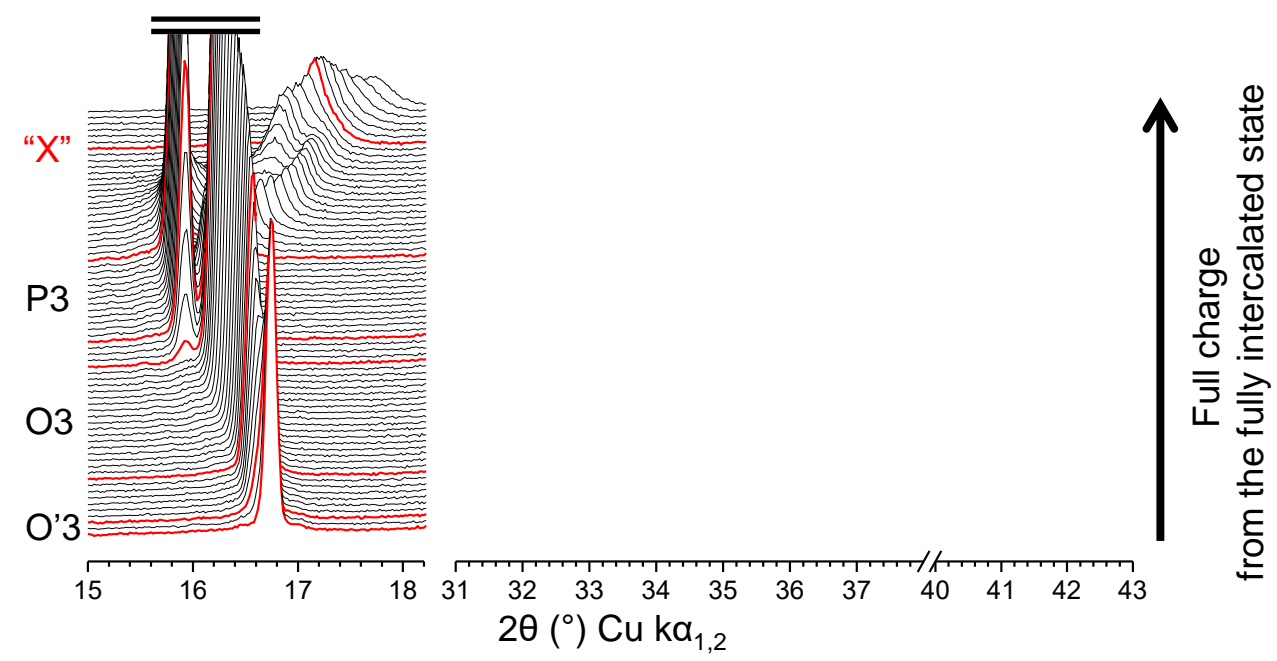

O3-Na0.77 $\mathrm{Mn}_{1 / 3} \mathrm{Fe}_{2 / 3} \mathrm{O}_{2}$ was studied by in situ XRPD. The system undergoes several structural transitions from $1.5 \mathrm{~V}$ to $4.3 \mathrm{~V}$ : O'3 $\rightarrow \mathrm{O} 3 \rightarrow \mathrm{P} 3 \rightarrow$ "X”. 


\section{ARTICLE}

Cite this: DOI: 10.1039/x0xx00000x

Received 00th January 2012,

Accepted 00th January 2012

DOI: $10.1039 / \times 0 \times x 00000 x$

www.rsc.org/

\section{$\mathrm{O3}-\mathrm{Na}_{x} \mathrm{Mn}_{1 / 3} \mathrm{Fe}_{2 / 3} \mathrm{O}_{2}$ as positive electrode material for Na-ion batteries: Structural Evolutions and Redox Mechanisms upon $\mathrm{Na}^{+}(\mathrm{De})$ intercalation}

\author{
B. Mortemard de Boisse, ${ }^{a}$ J.-H. Cheng, ${ }^{a, b}$ D. Carlier, ${ }^{* a}$ M. Guignard, ${ }^{a}$ C.-J. Pan, ${ }^{b}$ \\ S. Bordère, ${ }^{a}$ D. Filimonov,${ }^{c}$ C. Drathen, ${ }^{d}$ E. Suard,${ }^{e}$ B.-J. Hwang, ${ }^{b, f}$ A. Wattiaux ${ }^{a}$ \\ and C. Delmas ${ }^{a}$
}

\begin{abstract}
The electrochemical properties of the O3-type $\mathrm{NaxMn}_{1 / 3} \mathrm{Fe}_{2 / 3} \mathrm{O}_{2}(x=0.77)$ phase used as positive electrode material in $\mathrm{Na}$ batteries were investigated in the $1.5-3.8 \mathrm{~V}, 1.5-4.0 \mathrm{~V}$ and $1.5-4.3 \mathrm{~V}$ ranges. We show that cycling the Na cells in a wider voltage range do not induce a significant gain on long term cycling as the discharge capacities reached for the three experiments are identical after the $14^{\text {th }}$ cycle. The structural changes the material undergoes from $1.5 \mathrm{~V}$ (fully intercalated state) to $4.3 \mathrm{~V}$ were investigated by operando in situ X-ray powder diffraction (XRPD) and were further characterized by ex situ synchrotron XRPD. We show that the low amount of $\mathrm{Mn}^{3+}$ ions $\left(\approx 33 \%\right.$ of total $\mathrm{M}^{n+}$ ions) is enough to induce a cooperative Jahn-Teller effect for all $\mathrm{MO}_{6}$ octahedra in the fully intercalated state. Upon deintercalation the material exhibits several structural transitions: $\mathrm{O}^{\prime} 3 \rightarrow \mathrm{O} 3 \rightarrow \mathrm{P} 3$. Furthermore, several residual phases are observed during the experiment. In particular, a small part of the $\mathrm{O} 3$ type is not transformed to $\mathrm{P} 3$ but is always involved in the electrochemical process. To explain this behaviour the hypothesis of an inhomogeneity, which is not detected by XRD, is suggested. All phases converge into a poorly crystallized phase for $x \approx 0.15$. The short interslab distance of the resulting phase strongly suggests an octahedral environment for the $\mathrm{Na}^{+}$ions. X-ray absorption spectroscopy and ${ }^{57} \mathrm{Fe}$ Mössbauer spectroscopy were used to confirm the activity of the $\mathrm{Mn}^{4+} / \mathrm{Mn}^{3+}$ and $\mathrm{Fe}^{4+} / \mathrm{Fe}^{3+}$ redox couples in the low and high voltage regions, respectively. ${ }^{57} \mathrm{Fe}$ Mössbauer spectroscopy also showed an increase of the disorder into the material upon deintercalation.
\end{abstract}

\section{Introduction}

The intensive study of sodium layered oxides as positive electrode of sodium batteries started in the 80's. Several systems were reported in the literature such as $\mathrm{Na}_{\mathrm{x}} \mathrm{CoO}_{2}{ }^{1}, \mathrm{Na}_{\mathrm{x}} \mathrm{NiO}_{2}{ }^{2}$, $\mathrm{Na}_{x} \mathrm{CrO}_{2}{ }^{2}, \mathrm{Na}_{\mathrm{x}} \mathrm{TiO}_{2}{ }^{3}, 4$ or $\mathrm{Na}_{x} \mathrm{MoO}_{2}{ }^{5}$. The interest in these materials decreased when the Li-ion battery technology was developed. This technology, which was first used in portable devices such as mobile phones and laptops, is now extended to power electric vehicles. However for intermittent stationary energy storage needs, for which weight and energy density are less important but where the price and abundance of the materials are the overriding criteria, the Na-ion battery technology appears to be more suitable. With that goal in mind, several sodium layered oxides based on the non-toxic Mn and / or Fe elements have been studied or re-investigated recently: $\mathrm{Na}_{x} \mathrm{MnO}_{2}{ }^{6-8}$, $\mathrm{Na}_{x} \mathrm{FeO}_{2}{ }^{9}, \quad{ }^{10}, \quad \mathrm{Na}_{\mathrm{x}}(\mathrm{Mn}, \mathrm{Fe}) \mathrm{O}_{2}{ }^{11-20}, \quad \mathrm{Na}_{\mathrm{x}}(\mathrm{Ni}, \mathrm{Mn}) \mathrm{O}_{2}{ }^{21-27}$, $\mathrm{Na}_{\mathbf{x}}\left(\mathrm{Mn}, \mathrm{Mg} \mathrm{O}_{2}{ }^{28}, \quad \mathrm{Na}_{\mathrm{x}}(\mathrm{Ni}, \mathrm{Fe}) \mathrm{O}_{2}{ }^{29}, \quad \mathrm{Na}_{\mathbf{x}}(\mathrm{Ni}, \mathrm{Fe}, \mathrm{Mn}) \mathrm{O}_{2}{ }^{30,31}\right.$, $\mathrm{Nax}(\mathrm{Ni}, \mathrm{Mn}, \mathrm{Co}) \mathrm{O}_{2}{ }^{32-39} \ldots$
Due to the large ionic radius of the $\mathrm{Na}^{+}$ion compared to the $\mathrm{Li}^{+}$ one (1.02 $\AA$ vs. $0.76 \AA$ respectively), and its ability to adapt either octahedral or trigonal prismatic $\mathrm{NaO}_{6}$ environments, several $\mathrm{Na}_{x} \mathrm{O}_{2} \quad(M=$ transition metal $)$ materials can be obtained depending on the $\mathrm{Na} / M$ ratio and on the synthesis conditions. Most of the alkali layered oxides exhibit a hexagonal / rhombohedral cell. Their structures can be classified into several families depending on the environment of the alkali ion (prismatic $(\mathrm{P})$ or octahedral $(\mathrm{O})$ ) and the number of metal-oxide slabs in the hexagonal cell ${ }^{40}$. When a structural distortion is observed, a prim sign is added. Therefore, P2, P'2, O3, O'3, P3 and $\mathrm{P}^{\prime} 3$ are the most common structures observed in the case of sodium layered oxides.

We recently reported the synthesis and preliminary structural and electrochemical studies of the $\mathrm{O} 3-\mathrm{Na} 0.82 \mathrm{Mn}_{1 / 3} \mathrm{Fe}_{2 / 3} \mathrm{O}_{2}$ phase, along with other $\mathrm{P} 2 / \mathrm{O} 3-\mathrm{Na}_{\mathrm{x}} \mathrm{Mn}_{1-\mathrm{y}} \mathrm{Fe}_{\mathrm{y}} \mathrm{O}_{2}$ phases $(y=1 / 3$, and $1 / 2)^{14}$. In this work, we present a more detailed study of the $\mathrm{Na}_{x} \mathrm{Mn}_{1 / 3} \mathrm{Fe}_{2 / 3} \mathrm{O}_{2}$ system using an $\mathrm{O} 3-\mathrm{Na} 0.77 \mathrm{Mn}_{1 / 3} \mathrm{Fe}_{2 / 3} \mathrm{O}_{2}$ phase as pristine material. Its structure refined from synchrotron $\mathrm{X}$-Ray 
and neutron diffraction data is reported as well as its behaviour as positive electrode material in $\mathrm{Na}$ batteries. We especially focused on the understanding of the structural modifications occurring during the $\mathrm{Na}^{+}$intercalation / deintercalation and the associated redox processes.

\section{Experimental}

The synthesis protocol of the pristine material using a selfcombustion synthesis is described in detail in a previous publication $^{14}$. Manganese, iron and sodium nitrates were dissolved along with glycine in deionized water. The targeted phase was $\mathrm{O} 3-\mathrm{Na} 0.82 \mathrm{Mn}_{1 / 3} \mathrm{Fe}_{2 / 3} \mathrm{O}_{2}$. A sodium excess of $10 \mathrm{wt} \%$ was used to take into account the high volatility of sodium during the forthcoming heat treatment. The mixture was then heated in a ceramic bowl placed in a sand bath $\left(T \approx 400^{\circ} \mathrm{C}\right)$. The product from the combustion reaction was then grinded and heated at 700 ${ }^{\circ} \mathrm{C}$ under air for $20 \mathrm{~h}$ and at $1000{ }^{\circ} \mathrm{C}$ under $\mathrm{O}_{2}$ for $5 \mathrm{~h}$. After the heat treatment, the powder was quenched down to room temperature (RT) and introduced into an Ar-filled glovebox to avoid oxidation and reaction with air moisture. The $\mathrm{Mn} / \mathrm{Fe}$ and $\mathrm{Na} / M$ ratios were confirmed by Inductively Coupled Plasma Absorption Emission Spectroscopy (ICP-AES). The characterization was carried out from $10 \mathrm{mg}$ of powder dissolved into boiling aqua regalia using a Varian 720ES apparatus. The $\mathrm{Mn} / \mathrm{Fe}$ and $\mathrm{Na} / M$ ratios obtained agree with the targeted formula.

The synchrotron X-ray powder diffraction (synchrotron XRPD) experiments were carried out at European Synchrotron Radiation Facility (ESRF) in Grenoble, France on the high resolution powder diffraction ID31 beamline (now beamline ID22). The powders were loaded in epoxy-sealed $1 \mathrm{~mm}$ diameter glass capillaries. The wavelength was equal to 0.399845(6) $\AA$ and was deduced from the refinement of a silicon reference (NIST 640c). All data were recorded twice between 0 and $44^{\circ}$ ( $2 \theta$ range $)(\approx 2 * 27 \mathrm{~min})$ and then merged with a $0.002^{\circ}$ step size. The Rietveld refinement of the structures based on the synchrotron XRPD patterns were carried out between 3 and $40^{\circ}$ though only the $3-20^{\circ} 2 \theta$ range is shown in this paper.

Neutron diffraction (ND) data was recorded on the D2B High Resolution diffractometer at Institut Laue Langevin (ILL) in Grenoble, France. The wavelength was $\approx 1.6 \AA$. The data collection and analysis were carried out in the $0-160^{\circ}$ angular range with a step size of $0.05^{\circ}$ and a total counting time of $7 \mathrm{~h}$ at room temperature. $2 \mathrm{~g}$ of powder were placed into an $8 \mathrm{~mm}$ diameter vanadium airtight sample holder loaded in an Ar-filled glovebox.

The X-ray powder diffraction (XRPD) data was recorded on a PANalytical Empyrean DY 1281 diffractometer equipped with a $\mathrm{Cu}$ anticathode and a $\mathrm{Ge}(111)$ monochromator in the $10-120^{\circ}$ angular range with a step of $0.008^{\circ}$ and a measurement time of $520 \mathrm{~s} /$ step (15h15 long measurement, continuous scan in 0.1 $\mathrm{mm}$ outer diameter glass capillaries).

All refinements from neutron, laboratory X-ray and synchrotron $\mathrm{X}$-ray powder diffraction patterns were carried out using the Jana2006 software ${ }^{41}$. To correct the absorption of the samples while taking into account the packing of the powder inside the capillaries, we considered the density of the powder to be half the theoretical one.

The electrochemical characterizations were carried out in $\mathrm{Na} / \mathrm{NaPF}_{6}$ in propylene carbonate (PC) $(1 \mathrm{M})+2$ weight $\%$ (wt $\%$ ) additives/O3- $\mathrm{Na}_{x} \mathrm{Mn}_{1 / 3} \mathrm{Fe}_{2 / 3} \mathrm{O}_{2}$ batteries assembled in 2032 type coin cells. The positive electrode consisted in a mixture of the active material/carbon black/polytetrafluoroethylene in a $77 / 17 / 6$ weight ratio (total mass $\approx 22 \mathrm{mg}$ ). The electrolyte was obtained by dissolution of $\mathrm{NaPF}_{6}$ (Alpha Aesar 99+\% purity) in propylene carbonate (Sigma-Aldrich anhydrous $99 \%$ purity) to reach a final concentration of $1 \mathrm{~mol}^{-1}$. Depending on the experiment, $2 \mathrm{wt} \%$ of vinyldiene carbonate (VC) (Sigma Aldrich) or fluoroethylene carbonate (FEC) (obtained through an industrial partner) were added or not, according to the literature ${ }^{42}$. The electrodes were separated by three layers of Whatman glass fibre sheet to avoid short-circuits due to dendrites formation. All galvanostatic data were recorded using a Biologic VMP3 in galvanostatic mode at the $\mathrm{C} / 50$ rate $\left(1\right.$ mole of $\mathrm{Na}^{+}$per formula unit (dis)charged in $50 \mathrm{~h}$ ). The Galvanostatic Intermittent Titration Technique experiment was carried out in a similar cell. It consisted in a succession of current pulses (30 minutes at C/50) and relaxation steps with a slope limitation of 4 $\mathrm{mV} \cdot \mathrm{h}^{-1}$.

Operando in situ XRPD was carried out using an in situ cell purchased from Laboratoire de Réactivité et de Chimie des Solides (LRCS, Amiens, France) ${ }^{43}$ on a Bruker D5000 diffractometer equipped with a $\mathrm{Cu}$ anticathode $\left(\mathrm{Cu} \mathrm{k} \alpha_{1,2}\right)$. The electrochemical part of the cell is similar to the one described above for the galvanostatic cycling with a total mass of $10.5 \mathrm{mg}$. No additives were used for this experiment. The cell was previously discharged to $1.5 \mathrm{~V}$ vs. $\mathrm{Na}^{+} / \mathrm{Na}$ and the voltage was maintained for several days in order to achieve equilibrium before recording the charge process. The current rate was C/80 during the charge process so we were able to record one XRPD pattern every $\Delta x \approx 0.013$. The selected angular ranges were $13-$ $20^{\circ}$ and $30-43^{\circ}$ with a step of $0.02^{\circ}$ size and an acquisition time of $\approx 4 \mathrm{~s} /$ step. The electrochemical properties of the cell were recorded and controlled using a Biologic VMP3.

The "relaxed" in situ experiment was carried out using a homemade in situ cell on a PANalytical Empyrean DY1281 diffractometer. The electrochemical part of the cell is similar to the one described before. After recording the XRPD pattern corresponding to the initial state of the material, the battery was charged at $\mathrm{C} / 50$ for 90 minutes $\left(\Delta \mathrm{x}=0.03 \mathrm{Na}^{+} /\right.$formula unit). The following relaxation step duration was equal to $5 \mathrm{~h}$. A XRPD pattern was recorded during the last 90 minutes of the relaxation step between 15 and $45^{\circ}$.

Ex situ samples with the chemical composition $\mathrm{Na}_{x} \mathrm{Mn}_{1 / 3} \mathrm{Fe}_{2 / 3} \mathrm{O}_{2}$ with desired $\mathrm{Na}$ contents were prepared in homemade Swagelok battery type. The positive electrode consisted of an active material/carbon black (80/20 weight ratio, $100 \mathrm{mg}$ total mass) mixture pressed into a $10 \mathrm{~mm}$ diameter pellet. No additives were used for these experiments. After assembling, the batteries were galvanostatically charged or discharged on a Biologic VMP3 at C/50 until they reached the targeted voltage 
corresponding to the desired composition. The voltage was then imposed until the current dropped to $\approx 0 \mathrm{~mA}$ or until it reached a stable value in case of some electrolyte degradation occurring during the potentiostatic step. The batteries were then introduced into an Ar-filled glovebox and the positive electrode was taken out of the battery to be washed 3 to 5 times with anhydrous dimethyl carbonate (Sigma Aldrich, $>99 \%$ purity).

X-ray Absorption Near Edge Structure (XANES) data were recorded at National Synchrotron Radiation Resource Center (NSRRC, Taiwan) on the 17C beam line. The in situ experiment was carried out in operando, at $\mathrm{C} / 50$, in a modified coin cell battery, the only difference in the electrochemical cell being the electrolyte used $\left(\mathrm{NaPF}_{6}\right.$ in ethylene carbonate : diethyl carbonate, $1: 1(1 \mathrm{M}))$ The cell was pierced to allow the photon beam to go through and covered with polyimide tape in order to maintain airtightness. The positive electrodes were designed the same way as for the galvanostatic experiments. The selected energy ranges were 6530-6600 $\mathrm{eV}$ and 7110-7160 eV for the manganese and iron elements, respectively (30 min acquisition), although only the 6535-6570 eV and 7110-7145 eV ranges are displayed in this work.

Mössbauer measurements were performed at room temperature with a constant acceleration Halder - type spectrometer using a ${ }^{57} \mathrm{Co}$ source (Rh matrix) in transmission geometry. The velocity was calibrated using pure iron metal as the standard material. The Mössbauer in situ experiment was carried out in a homemade in situ cell. The positive electrode consisted of a $100 \mathrm{mg}$ pellet of active material and carbon black mixture (80/20 weight ratio, diameter $13 \mathrm{~mm}$, pressed for $1 \mathrm{~min}$ under 4 tons pressure). No electrolyte additives were used for this experiment. The cell was previously discharged and placed at $1.5 \mathrm{~V} v s . \mathrm{Na}^{+} / \mathrm{Na}$ before the experiment to reach the equilibrium for the intercalated phase. The cell was then charged at $\mathrm{C} / 100$ and placed under constant voltage during 48-72 $\mathrm{h}$ to reach equilibrium for the targeted composition. The spectra were recorded under constant voltage of the cell for $48 \mathrm{~h}$ at RT.

All voltages mentioned in the present work are expressed $v s$. the $\mathrm{Na}^{+} / \mathrm{Na}$ redox couple.

\section{Results and discussion}

\section{Synchrotron, X-ray and neutron diffraction studies of the pristine material}

In our previous work on $\mathrm{O} 3-\mathrm{Na} 0.82 \mathrm{Mn}_{1 / 3} \mathrm{Fe}_{2 / 3} \mathrm{O}_{2}{ }^{14}$, we mentioned the possible existence of transition metal vacancies within the $M \mathrm{O}_{2}$ slabs, based on the electrochemical cycling and according to previous work on $\mathrm{P} 2-\mathrm{Na}_{x} \mathrm{MnO}_{2}$ phases ${ }^{44,}{ }^{45}$. The vacancies arise from the spontaneous oxidation of the $\mathrm{Mn}^{3+}$ ions according to the reaction: $4 \mathrm{Mn}^{3+} \rightarrow 3 \mathrm{Mn}^{4+}+\square$. In order to determine the presence of these vacancies, we made synchrotron $\mathrm{X}$-ray and neutron powder diffraction experiments.

The collected synchrotron diffraction pattern and the calculated diagram resulting from the structural Rietveld refinement method are shown in Figure 1. The corresponding cell and atomic parameters are reported in Table 1. The lattice parameters of the $\mathrm{O} 3$ hexagonal cell ( $R-3 m$ space group): $a_{\text {hex. }}=$ $2.98195(3) \AA$ and $c_{\text {hex. }}=16.3420(2) \AA$ are close to our previous results $\left(a_{\text {hex. }}=2.9810(1) \AA \text { and } c_{\text {hex. }}=16.321(1) \AA\right)^{14}$. The small difference between the values of the $c_{\text {hex. }}$ parameters could result from slightly different sodium contents between the samples. The excellent data quality allowed us to refine the various atomic displacement parameters (ADP). In a first step, the total $\mathrm{Mn}+\mathrm{Fe}$ site occupancy was fixed equal to 1.0 and the ADP value for the transition metal ions refined to $0.47(2) \AA^{2}$. The occupancy and ADP of the $\mathrm{Na}^{+}$ion are equal to $0.77(1)$ and $1.3(1) \AA^{2}$ respectively. This high value of the $\mathrm{Na}^{+}$ion ADP can result from the high mobility of the $\mathrm{Na}^{+}$ion into the interslab space and is common in these materials ${ }^{37}, 46,47$. The final sodium content determined by synchrotron XRPD $(x=0.77(1))$ is lower than the theoretical one $(x=0.82)$ and the one determined by ICP-AES analysis $(x=0.83(2))$. This indicates that a small portion of the Na-ions were expelled from the material, probably during the air quenching step or by reaction with traces of oxygen and water in the glovebox. Note that the occupancy of the $\mathrm{O}$ site is fixed equal to 1.0 , thus only the corresponding ADP value is refined and is equal to $0.75(8) \AA^{2}$. In a second step, the transition metal site occupation was refined. All attempts did not lead to a significant conclusion on the existence of transition metal vacancies, as the occupancy of the transition metal site did not deviate significantly from 1.0. Therefore, in the following, the O3$\mathrm{Na} 0.77 \mathrm{Mn}_{1 / 3} \mathrm{Fe}_{2 / 3} \mathrm{O}_{2}$ formula will be considered for the pristine material. If one assumes that all iron ions are trivalent, there is $0.23 \mathrm{Mn}^{4+}$ and $0.10 \mathrm{Mn}^{3+}$ per formula unit.

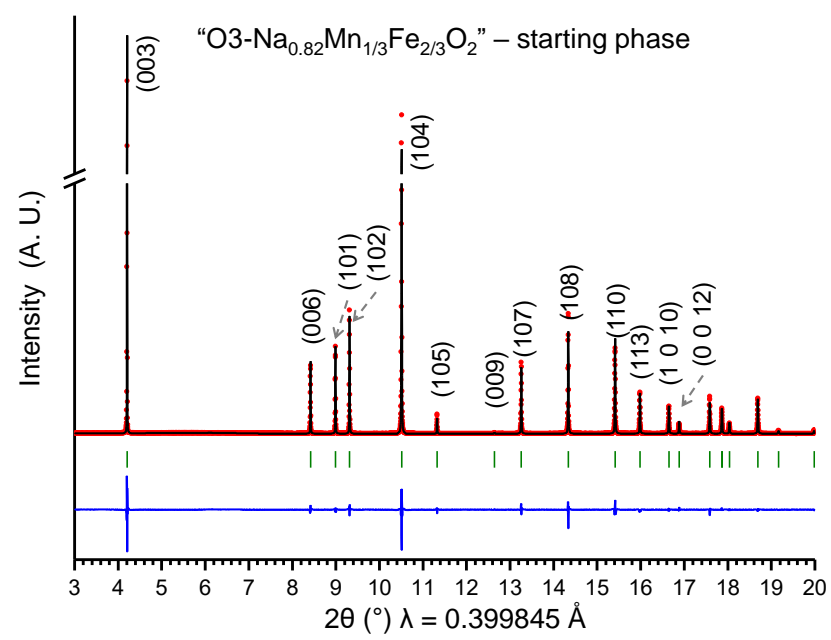

Figure 1. Observed and calculated (Rietveld method) synchrotron diffraction pattern for the O3-" $\mathrm{Na}_{0.82} \mathrm{Mn}_{1 / 3} \mathrm{Fe}_{2 / 3} \mathrm{O}_{2}$ " starting phase at room temperature. Red crosses: experimental, black line: calculated, blue line: difference and green bars: Bragg positions. 
The presence of $\mathrm{Mn}^{3+/ 4+}$ and $\mathrm{Fe}^{3+}$ ions in the $1 / 2$ ratio lead us to consider the possibility of an ordering within the transition metal layer even if the difference in ionic radii $\left(\mathrm{Mn}^{3+}(\mathrm{r}=0.58\right.$ $\left.\AA), \mathrm{Mn}^{4+}(\mathrm{r}=0.53 \AA), \mathrm{Fe}^{3+}(\mathrm{r}=0.63 \AA)\right)$ is not very large. Contrarily to XRPD, neutron diffraction allows distinguishing $\mathrm{Fe}$ from Mn thanks to the very different Fermi lengths (equal to $3.73 \mathrm{fm}$ and $+9.93 \mathrm{fm}$ for the ${ }^{55} \mathrm{Mn}\left(100 \%\right.$ abundance) and ${ }^{56} \mathrm{Fe}$ (91.75\% abundance) nuclei, respectively). Figure S1 and Table $\mathrm{S} 1$ give the results obtained from the neutron diffraction study. As no superstructure peak appears in the neutron diffraction pattern, we conclude that the O3-Na0.77 $\mathrm{Mn}_{1 / 3} \mathrm{Fe}_{2 / 3} \mathrm{O}_{2}$ does not exhibit any ordering between the transition metal ions. Note that the neutron Rietveld refinement leads to a final content of $0.68(1)$ $\mathrm{Fe}$ and $0.32(1) \mathrm{Mn}$, in good agreement with the expected stoichiometry and the ICP measurements.

Table 1. Structural parameters and reliability factors calculated from the synchrotron diffraction powder pattern of the "O3- $\mathrm{Na}_{0.82} \mathrm{Mn}_{1 / 3} \mathrm{Fe}_{2 / 3} \mathrm{O}_{2}$ " starting phase.

\begin{tabular}{|c|c|c|c|c|c|c|}
\hline \multicolumn{7}{|c|}{$\begin{array}{l}\text { Space group: } \mathbf{R - 3 m} \\
\mathrm{a}_{\text {hex. }}=2.98195(3) \AA, c_{\text {hex. }}=16.3420(2) \AA\end{array}$} \\
\hline Atom & Wyckoff & \multicolumn{3}{|c|}{ Coordinates } & Occ. & $\begin{array}{l}\mathrm{ADP} \\
\left(\AA^{2}\right)\end{array}$ \\
\hline $\mathrm{Na}$ & $3 b$ & 0 & 0 & $1 / 2$ & $0.77(1)$ & $1.3(1)$ \\
\hline $\mathrm{Mn}$ & $3 a$ & 0 & 0 & 0 & $1 / 3$ & $047(2)$ \\
\hline $\mathrm{Fe}$ & $3 a$ & 0 & 0 & 0 & $2 / 3$ & $0.4 /(2)$ \\
\hline $\mathrm{O}$ & $6 c$ & 0 & 0 & $0.269(1)$ & 1 & $0.75(8)$ \\
\hline
\end{tabular}

\section{Electrochemical characterizations}

In our previous study, we reported the cycling properties of $\mathrm{O} 3-\mathrm{Na} 0.82 \mathrm{Mn}_{1 / 3} \mathrm{Fe}_{2 / 3} \mathrm{O}_{2}$ as positive electrode material in a $\mathrm{Na}$ cell using $\mathrm{NaPF}_{6}$ in $\mathrm{PC}(1 \mathrm{M})$ as electrolyte ${ }^{14}$. However, the curves were severely shifted towards low $x$ values for an increasing number of cycles and we concluded that the $\mathrm{NaPF}_{6}$ in PC (1M) electrolyte was oxidized above approximately $3.5 \mathrm{~V}$. In order to optimize the cycling properties, we investigated the influence of electrolyte additives using an upper cut-off voltage of $3.8 \mathrm{~V}$. Figure 2 shows the first four cycles obtained from O3$\mathrm{Na}_{0.77} \mathrm{Mn}_{1 / 3} \mathrm{Fe}_{2 / 3} \mathrm{O}_{2}$ (starting by a discharge) using $\mathrm{NaPF}_{6}$ in $\mathrm{PC}$ (1M) electrolyte (Figure $2 \mathrm{a}$ ) or $\mathrm{NaPF}_{6}$ in $\mathrm{PC}(1 \mathrm{M})+2 \mathrm{wt} \%$ FEC (Figure $2 \mathrm{~b}$ ). Note that cycling the cells starting by a charge does not lead a significant change in the cycling behavior. The first cycle is highlighted in red for both experiments. The corresponding capacity retentions upon cycling are given in Figure 2c. The electrolyte involving $2 \mathrm{wt} \%$ of $\mathrm{VC}$ as an additive was also studied and the corresponding cycling curves are given in Figure S2. The use of $2 \mathrm{wt} \%$ of VC or FEC additives in the electrolyte clearly prevents from the electrolyte decomposition in the $1.5-3.8 \mathrm{~V}$ voltage window, leading to a better overlap of the cycling curves and to better capacity retention. A discharge capacity of 132 mAh. $\mathrm{g}^{-1}$ is reached on the second cycle in this voltage range and the capacity retention is equal to $92 \%$ at the $12^{\text {nd }}$ cycle. After further cycling, the behaviour strongly depends on the electrolyte used: without additive (in blue) a sudden decrease of the capacity is observed in agreement with our
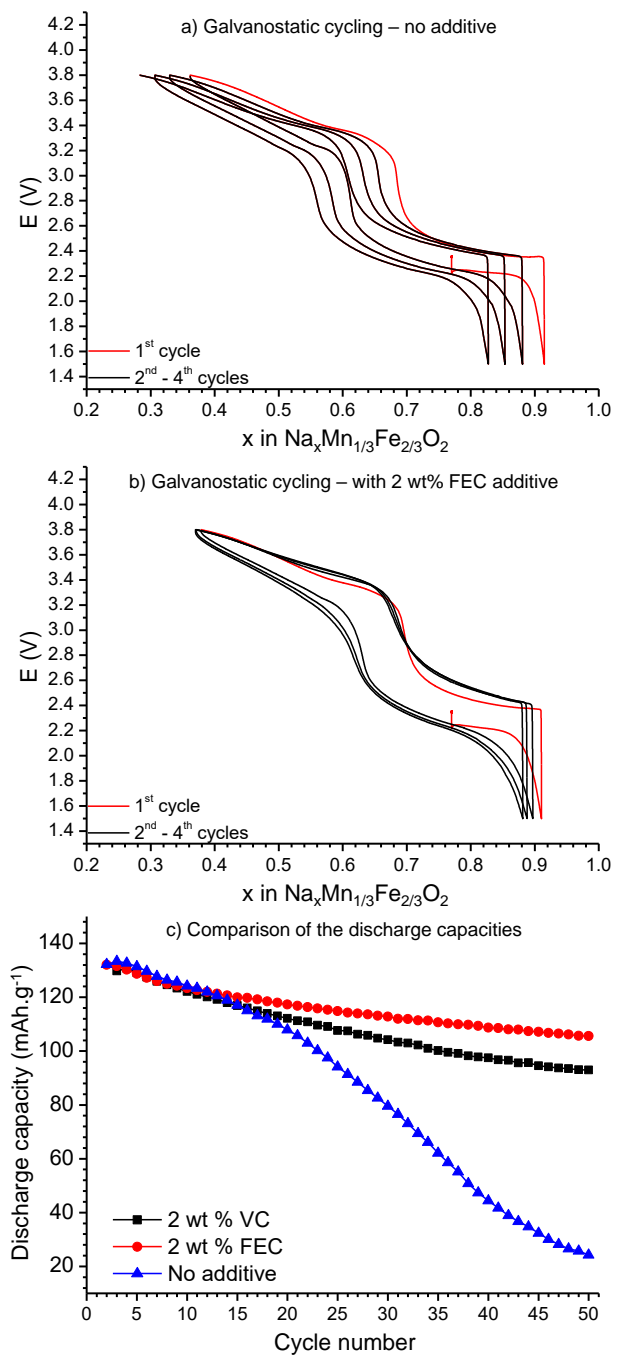

Figure 2. Galvanostatic cycling curves recorded between 1.5 and $3.8 \mathrm{~V}$ at $\mathrm{C} / 50$ (a) without any additive, (b) with the FEC electrolyte additive and (c) associated discharge capacities, including the experiment with the VC electrolyte additive presented in Figure S2.

previous study ${ }^{14}$. Thanks to the use of additives, the capacity fading is reduced.

Looking closely at the galvanostatic curves corresponding to the experiment using the VC additive (Figure S2), one can see the occurrence of a small incident on the second discharge curve at $\approx 2.15 \mathrm{~V}$ and then on the third and fourth discharge curves at $\approx 1.9 \mathrm{~V}$. As this accident only appears after the first charge and with VC, it seems to correspond to a side-reaction product created during charge. More experiments are needed to determine the nature of this side-reaction which seems to have a negative impact on the capacity retention.

From this study we concluded that FEC leads to better results than VC and was then further used for our studies. In the literature, FEC was also shown to play a key role in preventing the electrolyte decomposition for $\mathrm{Na}_{x} \mathrm{MO}_{2}$ materials ${ }^{42}$.

In a second step, we investigated the impact of the upper cutoff voltage on the electrochemical properties. The cycling curves obtained in the $1.5-4.0 \mathrm{~V}$ and $1.5-4.3 \mathrm{~V}$ ranges are given in 

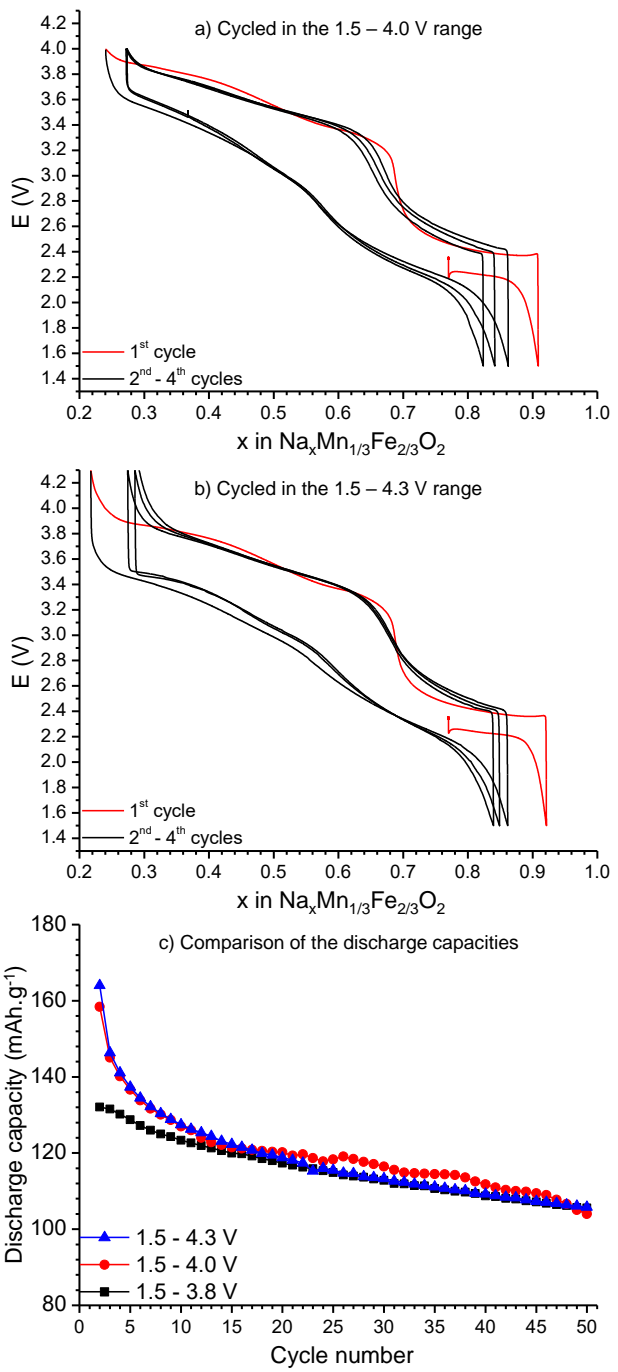

Figure 3. Galvanostatic cycling curves recorded (a) between 1.5 and 4.0 $\mathrm{V}$ and (b) between 1.5 and $4.3 \mathrm{~V}$ at $\mathrm{C} / 50$ with the FEC electrolyte additive. (c) Associated discharge capacities. The capacities of the first cycles are not shown on (c) as they correspond to the partially intercalated state of the material.

Figures $3 \mathrm{a}$ and $3 \mathrm{~b}$ respectively (as previously, the first four cycles are shown, starting by a discharge and the first cycle is highlighted in red). The one obtained in the $1.5-3.8 \mathrm{~V}$ range is already shown in Figure 2b. Figure $3 \mathrm{c}$ gives the evolution of the capacity retention in the three cases.

The increase of the upper cut-off voltage above $3.8 \mathrm{~V}$ clearly induces an extra capacity for the first cycle (Figure 3c), associated to a higher polarization of the curve. The discharge capacities of the batteries cycled up to 4.0 and $4.3 \mathrm{~V}$ are comparable and follow the same decrease tendency toward the values of cell cycled up to $3.8 \mathrm{~V}$, which is reached approximately after the $14^{\text {th }}$ cycle. Scanning Electron Microscopy micrographs taken after the galvanostatic experiments $(50$ cycles) for the different voltage ranges, highlight the formation of cracks and exfoliation in all cases (Figure S3). showing that no extra damages are formed for the materials cycled up to $4.3 \mathrm{~V}$.
For a better understanding of this system, we performed a Galvanostatic Intermittent Titration Technique (GITT) experiment (Figure 4).

Starting with a discharge from $\mathrm{x}=0.77$, the material exhibits a reversible plateau at low voltage $(x>0.85)$ corresponding to a biphasic domain. Upon charging and after the voltage plateau ( $x$ $<0.85$ ), the voltage continuously increases and overcomes a sudden jump at $x \approx 0.67$. This voltage jump seems to correspond to the change in the active redox process: from $\mathrm{Mn}^{3+} \rightarrow \mathrm{Mn}^{4+}$ to $\mathrm{Fe}^{3+} \rightarrow \mathrm{Fe}^{4+}$. During further charging $(0.4<x<0.65)$, the voltage slightly increases and the polarization is weak. As it will be discussed later, this can result from the higher ionic conductivity of the $\mathrm{P} 3$ phase or from the involvement of the $\mathrm{Fe}^{4+} / \mathrm{Fe}^{3+}$ redox couple. Then, above $3.8 \mathrm{~V}(x \approx 0.37)$, the curve describes a voltage plateau followed by a graduated increase of the polarization with the upper voltage. This strongly suggests that a new and unknown reaction occurs at high voltage.

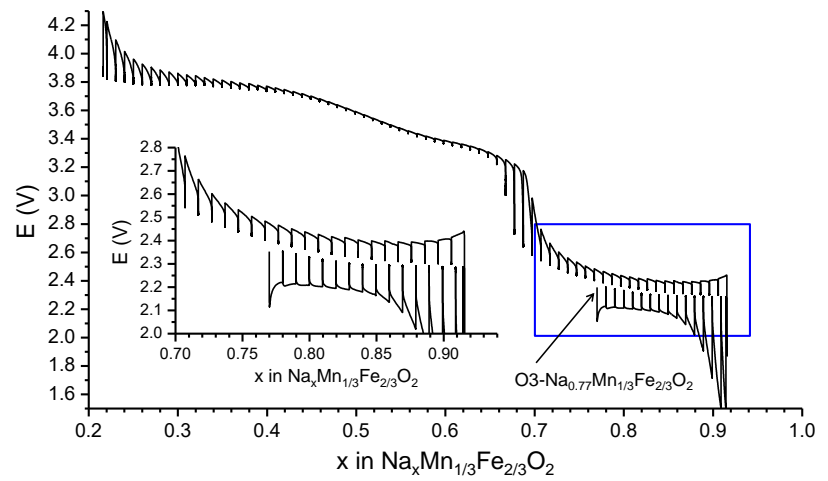

Figure 4. GITT cycling curve of the $\mathrm{Na}_{\mathrm{x}} \mathrm{Mn}_{1 / 3} \mathrm{Fe}_{2 / 3} \mathrm{O}_{2}$ system recorded with steps of $\approx 0.01 \mathrm{Na}$ per formula unit. Relaxation condition: $\Delta \mathrm{V}<4$ $\mathrm{mV} \cdot \mathrm{h}^{-1}$.

\section{Operando in situ study during the full charge of the battery}

In order to study the structural changes that the material undergoes during $\mathrm{Na}^{+}$deintercalation, we carried out an operando in situ XRPD study. Data were collected during the first charge following a preliminary discharge of the cell that lead to the $\mathrm{Na}_{0.96} \mathrm{Mn}_{1 / 3} \mathrm{Fe}_{2 / 3} \mathrm{O}_{2}$ composition as the starting point. In order to be close to the fully intercalated phase, the galvanostatic discharge was followed by a potentiostatic intercalation at $1.5 \mathrm{~V}$ until the current was close to $0 \mathrm{~mA}$. Selected parts of the resulting XRPD patterns are shown in Figure 5a along with the corresponding charging curve of the battery up to $4.3 \mathrm{~V}$ (Figure $5 b)$. For clarity, the same plot is presented in inverse order in the supplementary information (Figure S4).

As the in operando mode implies that the material is characterized out of equilibrium, the structural changes occurring during charge are only discussed qualitatively. The structural parameter values given in the following might 


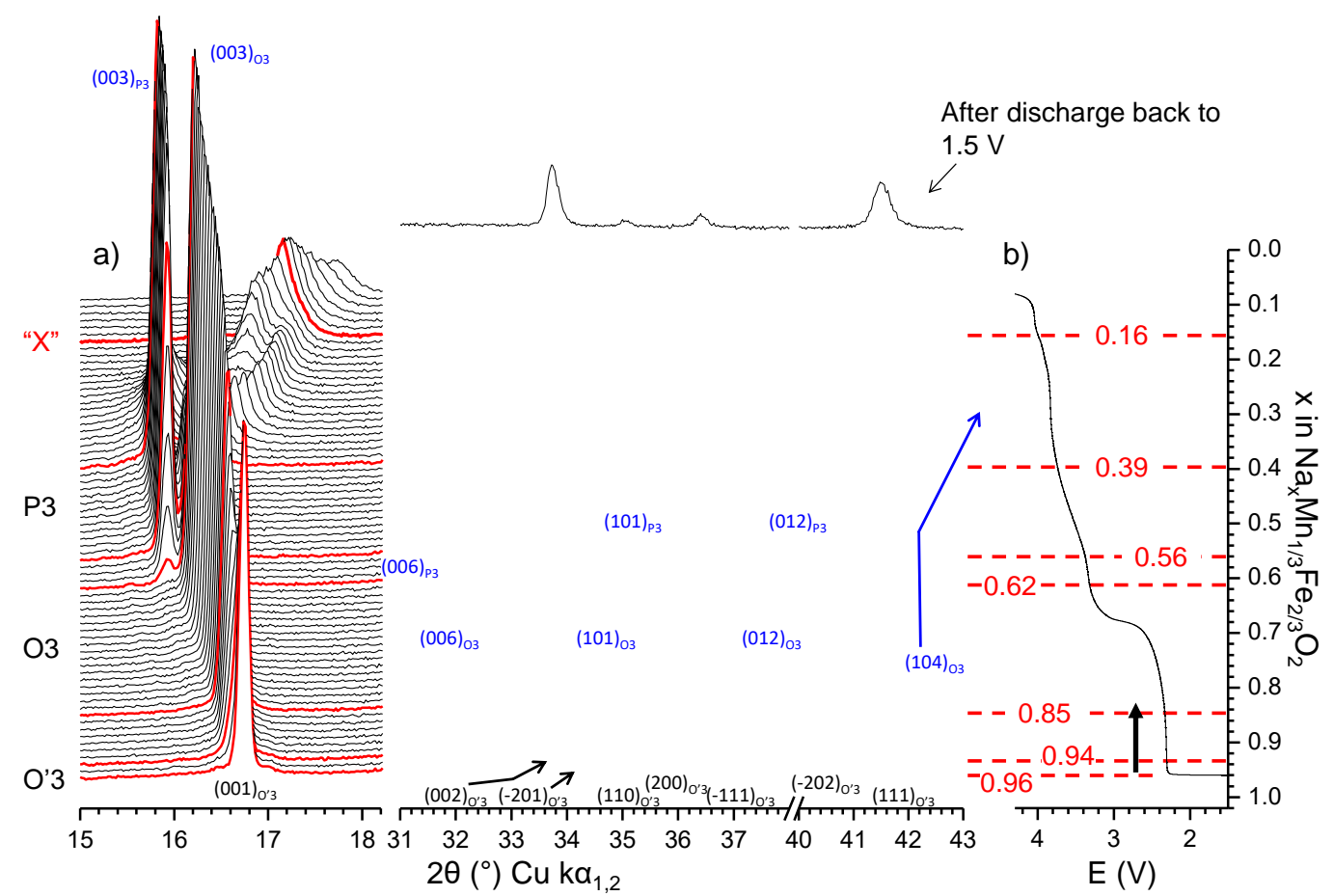

Figure 5. (a) Operando XRPD patterns recorded during the charge of a $\mathrm{Na}_{\mathrm{x}} \mathrm{Mn}_{1 / 3} \mathrm{Fe}_{2 / 3} \mathrm{O}_{2} / \mathrm{NaPF}_{6}$ in PC (1M)/Na in situ cell along with (b) the corresponding galvanostatic. Blue Miller indexes: $\mathrm{O} 3$ and $\mathrm{P} 3$ phases. Black Miller indexes: O'3 phase.

therefore slightly differ from those of the material in its relaxed state. The interslab distance, i.e. the distance between the transition element layers of two distinct $\mathrm{MO}_{2}$ planes, can be estimated from the peak position of the $(001)_{\text {mon. }}$ or $(003)_{\text {hex. }}$ reflections. The interslab distances are related to the $c_{\text {hex. }}$ or $c_{\text {mon. }}$. cell parameters by the following equations: $c_{\text {hex. }} / 3(\mathrm{O} 3, \mathrm{P} 3)$ or $c_{\text {mon. }} \sin (\beta)\left(\mathrm{O}^{\prime} 3\right)$. The evolution of the interslab distances and of the $a_{\text {mon. }}, b_{\text {mon. }}$ and $a_{\text {hex. }}$ cell parameters are reported in Figure 6 along with the cycling curve. An increase of the interslab distance is expected when the screening effect of the $\mathrm{Na}^{+}$ions on the surrounding $\mathrm{O}$ planes is reduced, that is when decreasing the $\mathrm{Na}$ content.

As it is further detailed, several structural changes occur during the charge. In the almost fully intercalated state a structural distortion (O'3) is observed. Sodium deintercalation leads to the formation of the $\mathrm{O} 3$ phase (the pristine one) through a biphasic domain in the $0.85 \leq x<0.94$ composition range. For $x<0.62$ the P3 structure type appears. It exhibits a larger interslab distance due to the prismatic environment of the sodium ions as shown by the $(00 l) \mathrm{P3}$ diffraction lines which appears at lower angles than the $(00 l)_{03}$ ones. The structural modification is clearly shown by the absence of the (104)P3 diffraction peak (Figure S4) which is always very weak on the XRPD patterns of $\mathrm{P} 3$ phases in comparison with the $\mathrm{O} 3$ ones. This structural change from $\mathrm{O} 3$ to $\mathrm{P} 3$ will be further confirmed by the ex situ synchrotron XRPD measurements.

Surprisingly the $\mathrm{O} 3$ type phase does not disappear completely upon charging (Figures 5 and S4). This unexpected result is reproducible and reversible if the battery is discharged. In order to check if this special behaviour is related to an experiment carried out of equilibrium, another in situ study was performed during a GITT charge, where the XRPD patterns were recorded at the end of each relaxation step $\left(\mathrm{dE} / \mathrm{dt}<2.6 \mathrm{mV} \cdot \mathrm{h}^{-1}\right)$. The same behaviour was also found and is presented in Figure S5. Obviously, for $x<0.62$, there is coexistence of two systems that are deintercalated simultaneously. This point will be further discussed in details.

The XRPD pattern of the initial phase of the operando in situ XRPD experiment, $\mathrm{Na}_{0.96} \mathrm{Mn}_{1 / 3} \mathrm{Fe}_{2 / 3} \mathrm{O}_{2}$ (end of discharge), can be indexed in the monoclinic system $\left(\mathrm{C} 2 / \mathrm{m}\right.$ space group, $\mathrm{O}^{\prime} 3$ structure). The monoclinic distortion of the cell is clearly emphasized by the splitting of the (012) hex. and (104)hex. diffraction lines of the $\mathrm{O} 3$ structure to the $(-111)_{\text {mon. }}+(200)_{\text {mon. }}$. and to the $(-202)_{\text {mon. }}+(111)_{\text {mon. }}$ ones, respectively. During $\mathrm{Na}^{+}$ deintercalation from $\mathrm{Na} 0.96 \mathrm{Mn}_{1 / 3} \mathrm{Fe}_{2 / 3} \mathrm{O}_{2}$, a very narrow composition domain is observed for the O' 3 phase $(0.94<x<$ 0.96), followed by a biphasic domain (characterized by the voltage plateau), observed for $0.85 \leq x \leq 0.94$. It appears that the interslab distance is slightly higher for the $\mathrm{O} 3$ phase $(\approx 5.40 \AA$ in average) than for the $\mathrm{O}^{\prime} 3$ one $(\approx 5.36 \AA$ in average). This is due to the lower $\mathrm{Na}$ content of the $\mathrm{O} 3$ phase.

For $0.62<x<0.85$ the system exhibits a solid solution with an $\mathrm{O} 3$ type structure as observed for the pristine material. As expected, the interslab distance increases as sodium is removed from the interlayer space. On the contrary, the $M-M$ in plane distance (approximated to the $a_{\text {hex. }}$ parameter) decreases as the average ionic size of the $M^{n+}$ ions decreases upon oxidation.

Upon further $\mathrm{Na}^{+}$deintercalation $(x<0.62)$, a new phase with a $\mathrm{P} 3$ type structure appears while the intensity of the $\mathrm{O} 3$ phase diffraction lines decreases. As previously mentioned, a 
significant part of the $\mathrm{O} 3$ type phase is still observed. The behaviour of this remaining phase upon $\mathrm{Na}^{+}$deintercalation will be considered later. As expected for a biphasic domain, the position of the (003) $\mathrm{P} 3$ line remains constant for $0.56<x<0.62$. Its shift to lower angles observed on further deintercalation indicates the occurrence of a solid solution $(0.39<x<0.56)$ for the P3 type phase.

When $x$ decreases below 0.39 the position of the (003)P3 line remains constant while its intensity decreases. Simultaneously, a broadening appears on the high angle side, which suggests the formation of stacking faults within the P3 phase. One can make the hypothesis that when a too large number of sodium ions are deintercalated from P3, the trigonal prismatic surrounding is destabilized. Therefore, some $M \mathrm{O}_{2}$ slabs glide to create an octahedral surrounding for the remaining $\mathrm{Na}^{+}$ions. This P3 phase with stacking faults is noted $\mathrm{P} 3-\mathrm{O} *$ in the following. The number of this type of octahedral interslab spaces continuously increases when $\mathrm{Na}^{+}$ions are deintercalated from the material, in agreement with the shift of the $(00 l)_{\mathrm{P} 3-\mathrm{O}}$ * diffraction line to lower $2 \theta$ angles. When the number of planes with octahedral

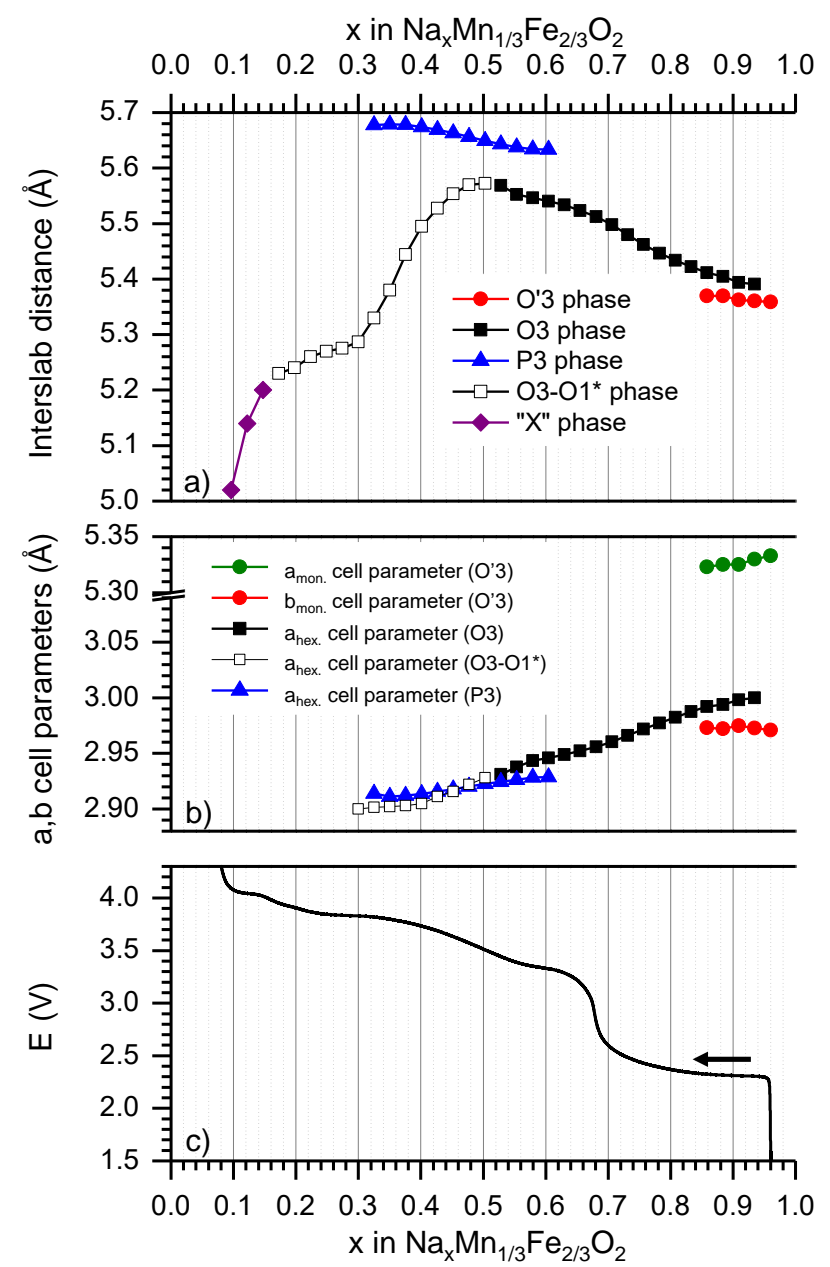

Figure 6. Evolution of (a) the interslab distance, and (b) the a and b cell parameters of the O'3, O3, O3-O1* and $\mathrm{P} 3$ phases upon sodium deintercalation as determined by LeBail refinement. The galvanostatic curve is showed as a guide on (c). surroundings is prevailing, a narrowing of the diffraction line is observed.

Simultaneously to the apparition of the P3 phase, we notice a continuous shift of the (003)03 diffraction peak to lower $2 \theta$ angles and down to $x=0.50$. On the opposite, when $x$ decreases

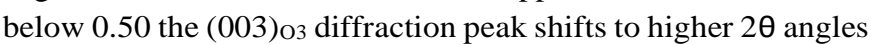
(Figure S6). The interslab distance therefore increases upon deintercalation $(x>0.5)$ and then decreases at the end of the charge $(x \leq 0.5)$. This behaviour is classically observed in all $\mathrm{O} 3$ type $\mathrm{A}_{x} \mathrm{MO}_{2}(\mathrm{~A}=\mathrm{Li}, \mathrm{Na})$ systems ${ }^{48}$. The decrease of the interslab distance in the $\mathrm{O} 3$ system for large deintercalation amount is due to the increase of bond covalence in the slabs. In a first step the $\mathrm{O} 3$ type structure is maintained while at the very end of the deintercalation the O1 type ("ABAB" packing) is formed by slab gliding as observed in the $\mathrm{Li}_{\mathrm{x}} \mathrm{CoO}_{2}$ and $\mathrm{Li}_{\mathrm{x}} \mathrm{NiO}_{2}$ systems ${ }^{49}, 50$. If in the present case we assume that the same behaviour is observed, we do not know where the limit is between the two processes due to the broadening of the few diffraction lines that are observed. This phase formed from $\mathrm{O} 3$ will therefore be referred to as $\mathrm{O} 3-\mathrm{O} 1 *$ in the later.

For $\mathrm{x}=0.16$, the $(00 l)$ diffraction peaks of the $\mathrm{O} 3-\mathrm{O} 1 *$ and $\mathrm{P} 3-\mathrm{O} *$ phases have merged into the $(00 l)_{\mathrm{X}}$ diffraction peak. This observation is in agreement with our hypothesis that both materials coming from the $\mathrm{O} 3-\mathrm{O} 1 *$ and $\mathrm{P} 3-\mathrm{O} *$ phases now possess an octahedral surrounding for the $\mathrm{Na}^{+}$ions. The small composition domain in which the O3-O1*, P3-O* and " $\mathrm{X}$ " phases are simultaneously observed $(0.16 \leq \mathrm{x} \leq 0.26)$ corresponds to the triphasic domain recently observed by Gonzalo et al. ${ }^{20}$. Upon further deintercalation, the $(00 l) \mathrm{x}$ diffraction line continuously shifts to lower $2 \theta$ angles which indicating a decrease of the interslab distance $\left(\mathrm{d}_{\text {interslab }} \approx 5.2 \AA\right.$ for $\mathrm{x}=0.15 v s$. $\mathrm{d}_{\text {interslab }} \approx 5.02 \AA$ for $\mathrm{x}=0.10$ ). For $\mathrm{x}<0.1$ the shift to lower $2 \theta$ values continues while a new broadening on the low angle side of the $(00 l)_{\mathrm{X}}$ diffraction peak appears. It could correspond to the formation of a more deintercalated phase via the formation of stacking faults and / or to a new biphasic domain. 
We already observed the formation of such a poorly

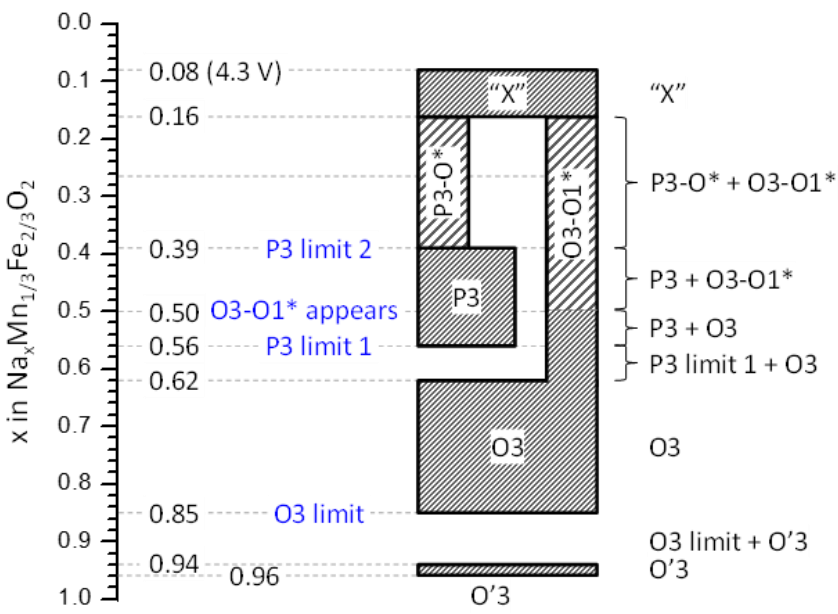

Figure 7. Schematic representation of the phase diagram of the $\mathrm{Na}_{\mathrm{x}} \mathrm{Mn}_{1 / 3} \mathrm{Fe}_{2 / 3} \mathrm{O}_{2}$ material upon $\mathrm{Na}$ deintercalation deduced from the operando in situ XRPD experiment. In the $0.16<\mathrm{x}<0.62$ range, several systems (related to $\mathrm{O} 3$ and $\mathrm{P} 3$ ) are simultaneously observed.

crystallized phase with short interslab distance for low intercalation contents in $\mathrm{P} 2-\mathrm{Na} 0.62 \mathrm{Mn}_{1 / 2} \mathrm{Fe}_{1 / 2} \mathrm{O}_{2}$ by operando in situ $\mathrm{XRPD}^{11}$. We also supposed that an octahedral surrounding for the $\mathrm{Na}^{+}$ions was created via a slab-gliding mechanism for low $x$ values $(x<0.25)$. The same tendency (formation of the $\mathrm{NaO}_{6}$ octahedral environment for highly deintercalated phases) was primarily stated by $\mathrm{Lu}$ and Dahn to explain the structural changes observed at the end of charge on the P2$\mathrm{Na}_{2 / 3} \mathrm{Mn}_{2 / 3} \mathrm{Ni}_{1 / 3} \mathrm{O}_{2}$ system by operando in situ XRPD. The authors suggested a slab-gliding mechanism leading to the $\mathrm{O} 2$ type structure for low intercalation rates ${ }^{21}$. Furthermore, they found an interslab distance equal to $4.32 \AA$, which is very similar to the $\mathrm{NiO}_{2}$ one ${ }^{49}$. The interslab distance in our material (approximatively 5.2-5.02 $\AA$ ) is in agreement with the presence of remaining $\mathrm{Na}^{+}$ions $(x=0.15-0.1)$. More recently, $\mathrm{Xu}$ et al. concluded on the formation of $\mathrm{NaO}_{6}$ octahedra and of an $\mathrm{O} 2$ structure to accompany the deintercalation of P2$\mathrm{Na} 0.80 \mathrm{Li} 0.12 \mathrm{Ni} 0.22 \mathrm{Mn} 0.66 \mathrm{O}_{2}$ by DFT calculations ${ }^{51}$. A schematic representation of the $\mathrm{Na}_{x} \mathrm{Mn}_{1 / 3} \mathrm{Fe}_{2 / 3} \mathrm{O}_{2}$ phase diagram is given in Figure 7.

The simultaneous presence of several phases with $\mathrm{O} 3$ and $\mathrm{P} 3$ based structures type involved in the deintercalation process is difficult to understand. To explain it, we can make the hypothesis of composition fluctuations that are not detected in XRPD data of the starting material: (i) the coexistence of particles with slightly different $\mathrm{Mn} / \mathrm{Fe}$ ratios or (ii) the existence of particles with or without $\mathrm{Mn}$ vacancies. It is well known that the relative stability of the $\mathrm{O} 3$ and $\mathrm{P} 3$ packings is directly correlated to the bond covalence within the slab and to the sodium amount ${ }^{40}$. In this hypothesis, a part of the $\mathrm{O} 3$ phase is going through deintercalation following a solid solution process while the other part is transformed into the P3 phase. Further experiments are required to confirm this behaviour.

To study the reversibility of the diverse structural transitions, we discharged the cell back to $1.5 \mathrm{~V}$ after it remained for $\approx 12 \mathrm{~h}$ at $4.3 \mathrm{~V}$, and recorded the XRPD pattern under constant voltage and with the same acquisition parameters. The XRPD patterns recorded after the first and second discharges are presented in

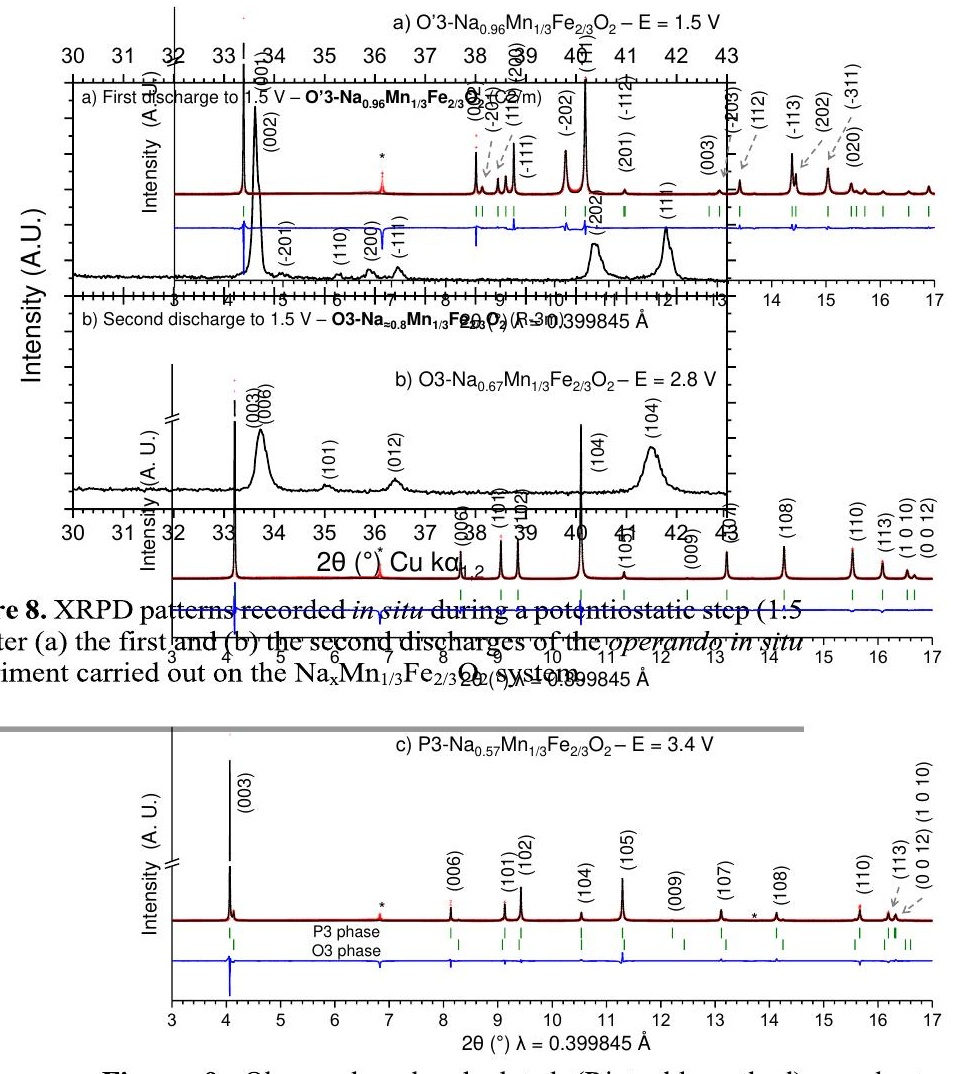

Figure 9. Observed and calculated (Rietveld method) synchrotron XRPD patterns from "ex situ samples" prepared at given equilibrium voltage values and representative of: (a) the O' 3 phase, (b) the $\mathrm{O} 3$ phase and (c) the P3 phase. The acquisitions were carried out at room temperature. Red crosses: experimental, black line: calculated, blue line: difference and green bars: Bragg positions. The ${ }^{*}$ symbol indicates the graphite diffraction, excluded for the refinements.

Figure 8. After the second discharge the monoclinic distortion is not observed. This results from the lower sodium content after the second discharge $(\mathrm{x} \approx 0.8)$. The $\mathrm{Mn}^{3+}$ content $(\approx 13 \%$ of the $M^{n+}$ ions) is not enough to induce the cooperative Jahn-Teller effect. The lower intercalated sodium content, even when the discharge voltage is fixed to $1.5 \mathrm{~V}$, implies that the material underwent an irreversible structural transition during the charge that may depend on the cycling conditions. Therefore a second experiment was performed. It consisted in cycling a $\mathrm{Na}_{x} \mathrm{Mn}_{1 / 3} \mathrm{Fe}_{2 / 3} \mathrm{O}_{2} / / \mathrm{Na}$ cell up to $4.3 \mathrm{~V}$ and then directly discharged it down to $1.5 \mathrm{~V}$. The positive electrode was then collected and analysed by ex situ XRPD (Figure S7). In these cycling conditions, both $\mathrm{O} 3$ and O'3 phases are observed on this XRPD pattern collected at $1.5 \mathrm{~V}$, indicating that the $\mathrm{O}^{\prime} 3$ formation can reversible, what seems to indicate that more $\mathrm{Na}^{+}$ ions could be intercalated then. The re-formation of the O'3 
phase during discharging clearly depends on the cycling conditions and especially here on the time of exposure of the cell at high voltage $(4.3 \mathrm{~V})$. The precise mechanism occurring at high voltage is not yet understood; migration of Fe into the interlayer space may be considered, as suggested to explain the poor electrochemical properties and structural stability of $\mathrm{Na}_{x} \mathrm{FeO}_{2}{ }^{52}$. Considering this hypothesis, the presence of a small amount of $\mathrm{Fe}$ ions at the sodium site would prevent from an overall intercalation as observed in the case of the $\mathrm{Li}_{1-\mathrm{z}} \mathrm{Ni}_{1+\mathrm{z}} \mathrm{O}_{2}$ systems $^{53}$.

\section{Ex situ synchrotron XRPD study}

In order to better understand the structural changes of the various $\mathrm{Na}_{x} \mathrm{Mn}_{1 / 3} \mathrm{Fe}_{2 / 3} \mathrm{O}_{2}$ phases, we prepared three samples and characterized them by ex situ synchrotron XRPD: (i) an O'3 phase (end of the first discharge, prepared using an equilibrium voltage $\mathrm{E}_{\mathrm{eq}}=1.5 \mathrm{~V}$ ), (ii) an $\mathrm{O} 3$ phase (middle of the voltage jump, $\mathrm{E}_{\mathrm{eq}}=2.8 \mathrm{~V}$ ) and (iii) a $\mathrm{P} 3$ phase $\left(\mathrm{E}_{\mathrm{eq}}=3.4 \mathrm{~V}\right)$. The experimental and calculated synchrotron XRPD Rietveld profiles are shown in Figures 9a, 9b and 9c respectively. All the associated Rietveld parameters are reported in Table 2. Materials

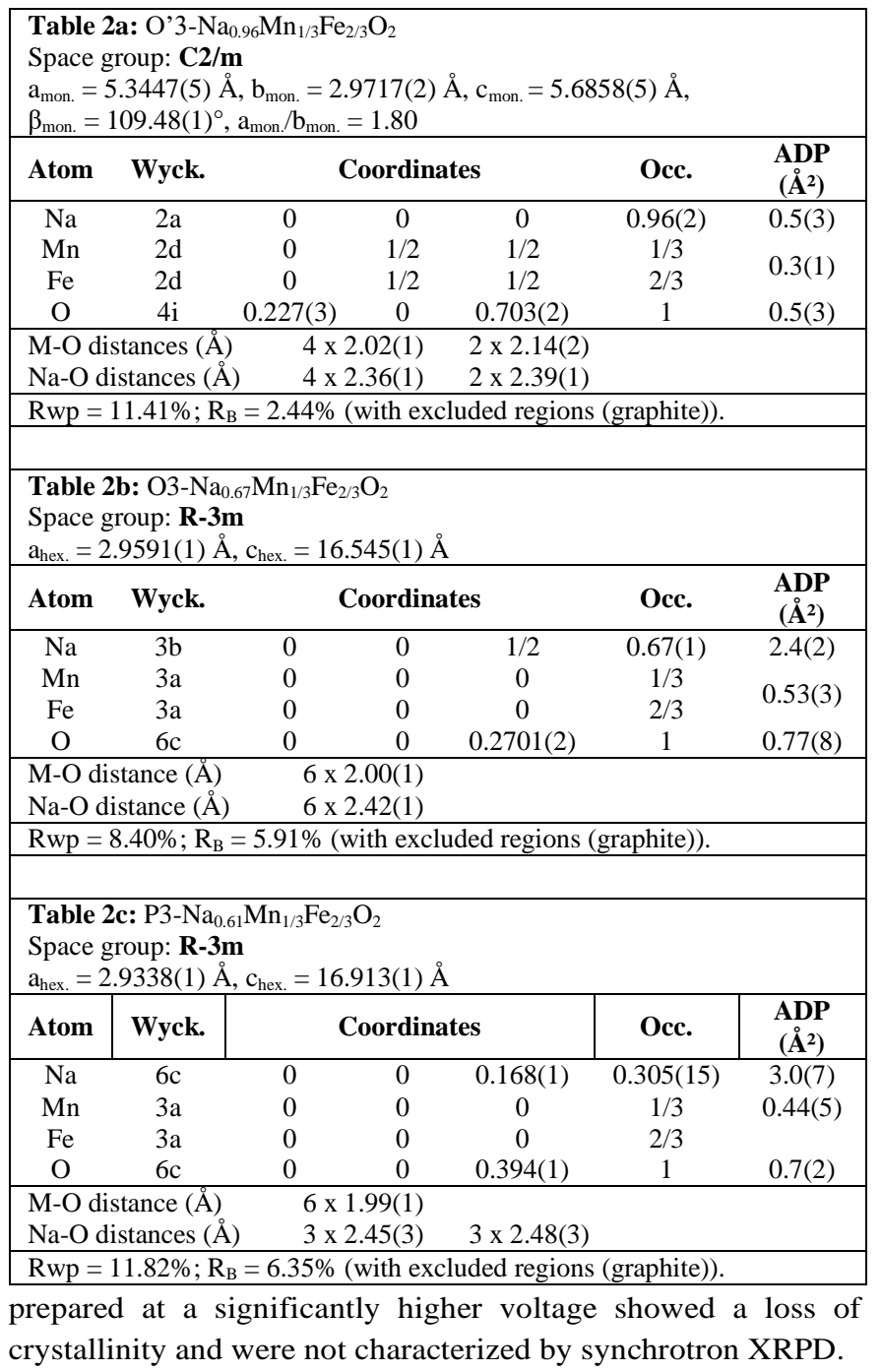

Table 2. Structural parameters and reliability factors calculated from the synchrotron diffraction powder patterns of the (a) O’3, (b) O3 and (c) P3 phases.

Figure 9a shows the experimental and calculated synchrotron XRPD patterns for the O'3-type phase. In order to correctly refine the peaks profiles we used a Pseudo-Voigt function and considered an anisotropic broadening through the use of tensor parameters as implemented in Jana 2006 Software $^{41}$. This method was already used to accurately describe complex structures that cannot be refined using conventional PseudoVoigt pattern matching refinement ${ }^{54}$. For layered materials, the selective broadening of some peaks often highlights the presence of stacking faults ${ }^{12,21,55}$. However, we do not observe a change in the broadening vs. the hkl values. In this case the broadening is more likely due to an evolution of the microstructure (e.g. stress / strain / coherent length domain / particle size).

In agreement with the in situ experiment, the pattern of the almost fully intercalated phase is indexed in space group $C 2 / \mathrm{m}$. Its monoclinic cell parameters are very close to those found for the $x=0.96$ composition in the in situ study. The refinement of the total $\mathrm{Na}$ content $(x=0.96(2))$ gives the formula of the intercalated phase: $\mathrm{O}^{\prime} 3-\mathrm{Na} 0.96 \mathrm{Mn}_{1 / 3} \mathrm{Fe}_{2 / 3} \mathrm{O}_{2}$. In alkali layered oxides, a distortion of the unit cell is often observed in presence of transition metal ions inducing a cooperative Jahn-Teller effect such as high spin HS-Mn ${ }^{3+} 44$ and low spin $\mathrm{LS}-\mathrm{Ni}^{3+}{ }^{56}$. The $a_{\text {mon. }} / b_{\text {mon. }}$ ratio is a good indicator of this distortion: in an ideal undistorted case (i.e. when the hexagonal $\mathrm{O} 3$ phase is described with a monoclinic cell), the $a$ mon. $/ b_{\text {mon. }}$ ratio is equal to $\sqrt{3}$ while it increases significantly when the cooperative Jahn-Teller distortion is involved (this ratio is equal to 1.99 in O'3- $\mathrm{NaMnO}_{2}$ for example $\left.{ }^{6,44}\right)$. In $\mathrm{Na}_{0.96} \mathrm{Mn}_{1 / 3} \mathrm{Fe}_{2 / 3} \mathrm{O}_{2}$ the $a_{\text {mon. }} / b_{\text {mon. }}$ ratio is equal to 1.80 . From the atomic positions, it appears that the $M_{6}$ octahedra show two long $M$-O bonds (2.14(2) $\AA$ ) and 4 shorter ones ((2.02(1) A) (Table 2a), confirming the cooperative JahnTeller effect. It is surprising that only a small amount of $\mathrm{Mn}^{3+}$ ions $(\approx 1 / 3$ of the transition metal ions) is enough to generate a cooperative distortion of the structure. The formation of this monoclinic phase is at the origin of the biphasic domain for $0.85 \leq x<0.96$.

Figure $9 \mathrm{~b}$ shows the experimental and calculated synchrotron XRPD diagrams corresponding to the composition associated to the middle of the voltage jump $\left(E_{e q}=2.8 \mathrm{~V}, x=0.67\right)$. The synchrotron XRPD data, fitted with a Pseudo-Voigt function, shows a pure $\mathrm{O} 3$ phase whose structure and cell parameters are comparable to those of the pristine material. The $c_{\text {hex. }}$ and $a_{\text {hex. }}$. cell parameters are larger (16.545(1) $\AA$ vs. 16.3420(2) $\AA$ ) and smaller (2.9591(1) $\AA$ vs. 2.98195(3) A) respectively than in the pristine material, in agreement with the slightly lower Na content ( $x=0.67$ vs. $x=0.77$ initially). Moreover, it is noteworthy that no extra-diffraction lines resulting from sodium / vacancy ordering are observed, as it is common in other $\mathrm{Na}_{2} / 3 \mathrm{OO}_{2}$ phases with only one transition metal ${ }^{57-59}$.

The synchrotron XRPD pattern of the sample prepared at $E_{e q}=3.4 \mathrm{~V}$, presented in Figure 9c, was successfully fitted with the P3-type phase, using a Pseudo-Voigt function and 

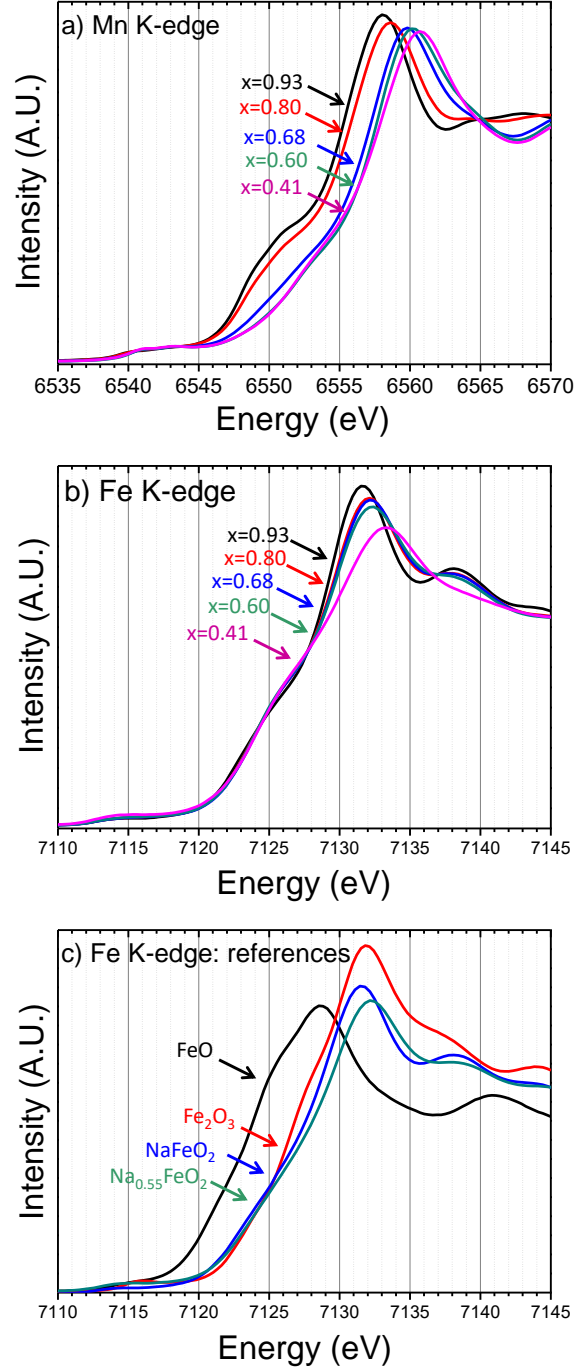

Figure 10. Operando In situ X-ray Absorption Near Edge Spectroscopy (XANES) spectra corresponding to (a) the Mn and (b) the Fe K-edges during the charge of a Na// $\mathrm{Na}_{\mathrm{x}} \mathrm{Mn}_{1 / 3} \mathrm{Fe}_{2 / 3} \mathrm{O}_{2}$ battery. The Fe references for $\mathrm{Fe}^{2+}(\mathrm{FeO}), \mathrm{Fe}^{3+}\left(\mathrm{Fe}_{2} \mathrm{O}_{3}, \mathrm{NaFeO}_{2}\right)$ and $\mathrm{Fe}^{3.45+}\left(\mathrm{Na}_{0.55} \mathrm{FeO}_{2}\right)$ are also given (c).

considering the use of anisotropic broadening. As one can see in Figure 9c, a small impurity of the $\mathrm{O} 3$ phase remains in the sample $(\approx 8 \mathrm{wt} \%)$. In the P3 stacking type, the sodium ion occupies a prismatic $\mathrm{NaO}_{6}$ site which shares a face and three edges with the surrounding $\mathrm{MO}_{6}$ octahedra. This change in coordination results from the gliding of two $M \mathrm{O}_{2}$ planes in the structure whose corresponding $\mathrm{O}$ positions move from an "ABCABC" stacking to an "ABBCCA" one. The refinement of the $\mathrm{Na}$ content leads to the $\mathrm{P} 3-\mathrm{Na} 0_{0.61(3)} \mathrm{Mn}_{1 / 3} \mathrm{Fe}_{2 / 3} \mathrm{O}_{2}$ formula. Due to a stronger electrostatic $\mathrm{Na}^{+}-M^{3+/ 4+}$ repulsion through the common $\mathrm{NaO}_{6} /$ $\mathrm{MO}_{6}$ face, the sodium ion is slightly off centered in its prismatic environment along the $c$-direction $\left(\mathrm{z}_{\mathrm{Na}}=0.168(1)\right.$ instead of $\mathrm{z}_{\mathrm{Na}}$ $=1 / 6$ if centered); separating the $\mathrm{Na}-\mathrm{O}$ distances into three long $(2.48(3) \AA)$ and three short ones $(2.45(3) \AA)$. The higher $\mathrm{Na}^{+}$ion diffusion expected in the P3 structure explains the huge decrease of the polarization at the $\mathrm{O} 3 \rightarrow \mathrm{P} 3$ transition that we discussed along with the GITT curve (Figure 4).

\section{Redox mechanisms study: in situ XANES and in situ ${ }^{57} \mathrm{Fe}$ Mössbauer spectroscopy}

In our previous study ${ }^{14}$, basing on the shape of the galvanostatic curves of the various materials, we suggested that the $\mathrm{Mn}^{4+} / \mathrm{Mn}^{3+}$ and $\mathrm{Fe}^{4+} / \mathrm{Fe}^{3+}$ redox couples were both active in the $1.5-3.8 \mathrm{~V}$ range for materials with $\mathrm{Mn} / \mathrm{Fe}$ ratios equal to 1 / 1 or $1 / 2$. In fact it is imposed by the material composition; the $\mathrm{Mn}^{4+} / \mathrm{Mn}^{3+}$ redox couple being active at lower voltage than $\mathrm{Fe}^{4+} / \mathrm{Fe}^{3+}$ one. In the present paper, we studied the redox processes by operando in situ XANES and in situ ${ }^{57} \mathrm{Fe}$ Mössbauer spectroscopy.

The XANES spectra at the Mn and Fe K-edges recorded in operando during the charge of a specific cell are presented in Figures $10 \mathrm{a}$ and $10 \mathrm{~b}$ respectively, along with the reference compounds used for the Fe K-edge (Figure 10c). The cell was discharged $(x=0.93)$ before the experiment.

For $0.67<x \leq 1$, one can notice an important shift of the Mn Kedge toward the higher energy values as $\mathrm{Na}^{+}$is deintercalated from the structure. We associate this shift to the $\mathrm{Mn}^{3+} \rightarrow \mathrm{Mn}^{4+}$ redox reaction. In the mean sodium content region, no significant shift is observed in the Fe $\mathrm{K}$-edge spectra, indicating that only the $\mathrm{Mn}^{4+} / \mathrm{Mn}^{3+}$ redox couple is active at low voltage (high sodium contents: $x>0.67)$.

For $x<0.67$, no significant shift is observed in the spectra corresponding to the Mn K-edge while a small one is observed for the $\mathrm{Fe} \mathrm{K}$-edge, despite being less accentuated than the one described above for the Mn K-edge. In order to obtain some references for the $\mathrm{Fe}(\mathrm{IV})$ oxidation state in this kind of materials, we prepared samples of the $\mathrm{O} 3-\mathrm{NaFeO}_{2}$ phase by solid state chemistry and of the $\mathrm{Na}_{0.55} \mathrm{FeO}_{2}$ phase by electrochemical deintercalation. Their XANES spectra, presented in Figure 10c, only show a small shift in the spectrum position to higher energy values with $\mathrm{Na}^{+}$deintercalation, which is similar to the behaviour observed in the $\mathrm{Na}_{x} \mathrm{Mn}_{1 / 3} \mathrm{Fe}_{2 / 3} \mathrm{O}_{2}$ material for $x<0.67$. This data supports our assumption that the $\mathrm{Fe}^{3+} \rightarrow \mathrm{Fe}^{4+}$ reaction occurs after full oxidation of the $\mathrm{Mn}^{3+}$ ions $(\mathrm{x}<0.67, \mathrm{E}>2.8 \mathrm{~V})$. To get a clear confirmation about the activity range of the $\mathrm{Fe}^{4+} / \mathrm{Fe}^{3+}$ redox couple, we performed additional in situ ${ }^{57} \mathrm{Fe}$ Mössbauer spectroscopy.

The Mössbauer spectrum of pristine $\mathrm{O} 3-\mathrm{Na} 0.77 \mathrm{Mn}_{1 / 3} \mathrm{Fe}_{2 / 3} \mathrm{O}_{2}$ exhibits a quadrupole doublet that can be fitted by a Lorentzian profile (Figure 11). The fit of the spectrum requires considering two Fe sites (Table 3 ). The corresponding isomer shifts $(\delta)$ are typical of high spin (HS) $\mathrm{Fe}^{3+}$ ions in octahedral sites and so the sites were labelled as $\mathrm{Fe}^{3+}(\mathrm{A})$ and $\mathrm{Fe}^{3+}(\mathrm{B})$. The Lorentzian absorption lines associated to these two sites are represented by the green and blue lines in Figure 11a, respectively. The higher value of the quadrupole splitting for the $\mathrm{Fe}^{3+}(\mathrm{A})$ site $(\Delta=0.88$ $\mathrm{mm} . \mathrm{s}^{-1}$ ) indicates that the local environment of the $\mathrm{FeO}_{6}$ octahedron is more impacted by the surrounding disorder than the $\mathrm{Fe}^{3+}(\mathrm{B})$ site $\left(\Delta=0.58 \mathrm{~mm} \cdot \mathrm{s}^{-1}\right)$. The populations $(\mathrm{P})$ give a majority of the $\mathrm{Fe}^{3+}(\mathrm{B})$ site $(75 \%)$. In the literature, Yabuuchi et al. also used two $\mathrm{Fe}^{3+}$ sites to fit the spectrum of P2- 
$\mathrm{Na}_{2 / 3} \mathrm{Mn}_{1 / 2} \mathrm{Fe}_{1 / 2} \mathrm{O}_{2}{ }^{12}$. Thorne et al. used two $\mathrm{Fe}^{3+}$ sites and a $\mathrm{Fe}^{4+}$

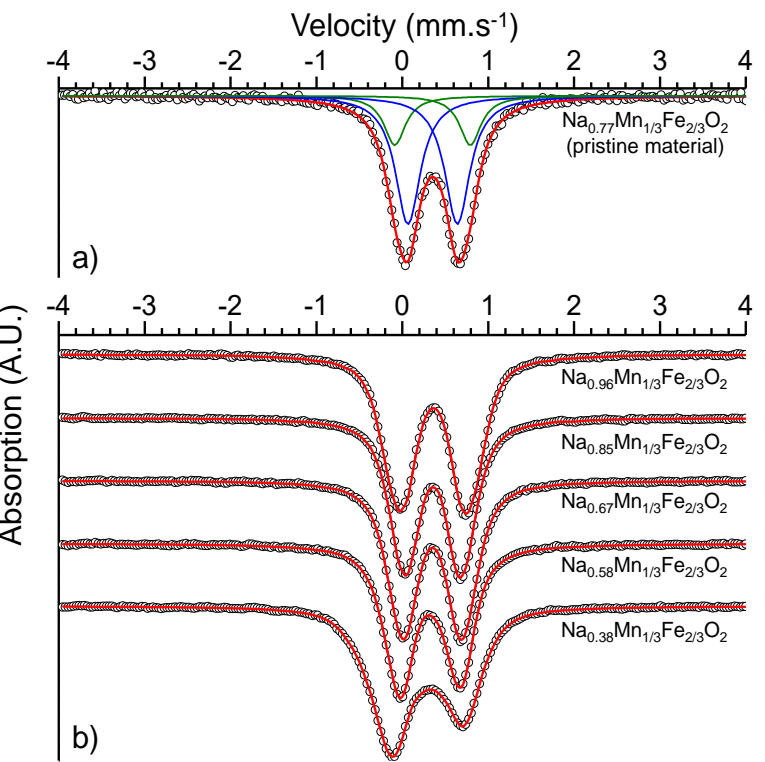

Figure 11. ${ }^{57} \mathrm{Fe}$ Mössbauer spectra (a) of the pristine material and (b) recorded in situ during the charge of a $\mathrm{Na} / \mathrm{Na}_{\mathrm{x}} \mathrm{Mn}_{1 / 3} \mathrm{Fe}_{2 / 3} \mathrm{O}_{2}$ battery. Black circles: experimental and red lines: calculated.

one to fit the spectra of $\mathrm{P} 2 / \mathrm{O} 3-\mathrm{Na}_{x} \mathrm{Mn}_{1-\mathrm{x}} \mathrm{Fe}_{\mathrm{x}} \mathrm{O}_{2}$ phases ${ }^{13}$.

Table 3. Mössbauer parameters (isomeric shift $(\delta)$, Full Width at Half Maximum (FWHM), quadrupole splitting $(\Delta)$ and Populations (P)) corresponding to the spectrum of the pristine material.

\begin{tabular}{|c|c|c|c|c|}
\hline Site & $\boldsymbol{\delta}\left(\mathbf{m m} \cdot \mathbf{s}^{\mathbf{- 1}}\right)$ & $\begin{array}{c}\text { FWHM } \\
\left(\mathbf{m m} . \mathbf{s}^{-1}\right)\end{array}$ & $\boldsymbol{\Delta}\left(\mathbf{m m} \cdot \mathbf{s}^{\mathbf{- 1}}\right)$ & $\mathbf{P}(\boldsymbol{\%})$ \\
\hline $\mathrm{Fe}^{3+}(\mathrm{A})$ & 0.353 & 0.30 & 0.88 & 25 \\
\hline $\mathrm{Fe}^{3+}(\mathrm{B})$ & 0.354 & 0.35 & 0.58 & 75 \\
\hline
\end{tabular}

We then conducted the in situ Mössbauer study during the electrochemical cycling. The spectra of the $\mathrm{Na}_{x} \mathrm{Mn}_{1 / 3} \mathrm{Fe}_{2 / 3} \mathrm{O}_{2}$ phases were recorded for selected sodium contents: $x=0.96$, $0.85,0.67,0.58$ and 0.38 during cell charge, following an initial discharge and after a negligible residual current was observed for each composition. The recorded spectra are shown in Figure 11b. As one can see, there is no significant variation of the peak positions for $0.67 \leq x \leq 0.96$ as highlighted in Figure S8a. On the opposite, there is a significant shift of the peak positions to lower velocity values for $x \leq 0.58$ (Figure $\mathrm{S} 8 \mathrm{~b}$ ). This indicates an oxidation of the $\mathrm{Fe}^{3+}$ ions.

As for the pristine material, all spectra exhibit a quadrupole doublet whose asymmetry and Full Width at Half Maximum (FWHM) increase as sodium is removed from the structure (Figure 11b).

A preliminary refinement using Lorentzian profile lines shows that several $\mathrm{Fe}^{\mathrm{n}+}$ sites are involved for each composition, as reported in Table 4 . For $0.67 \leq x<1$, two $\mathrm{Fe}^{3+}$ sites $(\delta \approx 0.34$ $-0.37 \mathrm{~mm} . \mathrm{s}^{-1}$ ) are required to describe the spectra. One can observe that the $\mathrm{Fe}^{3+}$ ions are not involved in the redox process at low voltage and that therefore only the $\mathrm{Mn}^{3+}$ are oxidized upon $\mathrm{Na}^{+}$deintercalation. For $x=0.58$ and $x=0.38$, we note the appearance of the $\mathrm{Fe}^{4+}\left(\delta \approx 0 \mathrm{~mm} \cdot \mathrm{s}^{-1}\right)$ and $\mathrm{Fe}^{(3+\mathrm{z})+}(\delta \approx 0.11-0.18$ $\left.\mathrm{mm} . \mathrm{s}^{-1}\right)$ sites, confirming that the $\mathrm{Fe}^{3+}$ ions are oxidized at high voltage.

We observe an important broadening of the FWHM of the spectra upon deintercalation for all compositions. This observation is coherent with the appearance of new Fe ${ }^{n+}$ sites. It also suggests an increasing disorder (bond length and charge distributions) in the material upon $\mathrm{Na}^{+}$deintercalation. To take into account this phenomenon a second calculation has been realized based on fixed isomer shifts deduced from the Lorentzian profile type refinement. Several experiments were performed to select the best FWHM values for each sodium amount in agreement with the range classically used in our spectrometer $\left(0.20-0.30 \mathrm{~mm} . \mathrm{s}^{-1}\right)$. To take into account the increasing disorder into the material upon $\mathrm{Na}^{+}$deintercalation the following FWHM values were used: 0.20 for the $x=0.96$ and 0.85 samples; 0.25 for the $x=0.67$ sample and 0.30 for the $x=$ 0.58 and 0.38 ones. From these distribution fittings, we determined the average quadrupole splitting $\left(\Delta^{*}\right)$ and the population of the different iron sites which are presented in Table 4 along with the developed formula and awaited $\mathrm{Fe}^{\mathrm{n}+}$ populations. The quadrupole splitting of the maxima of the distribution $\left(\Delta_{\max }\right)$ is also given.

The spectra corresponding to the $x=0.96,0.85$ and 0.67 samples are quite similar as shown in Figure S8a and can be

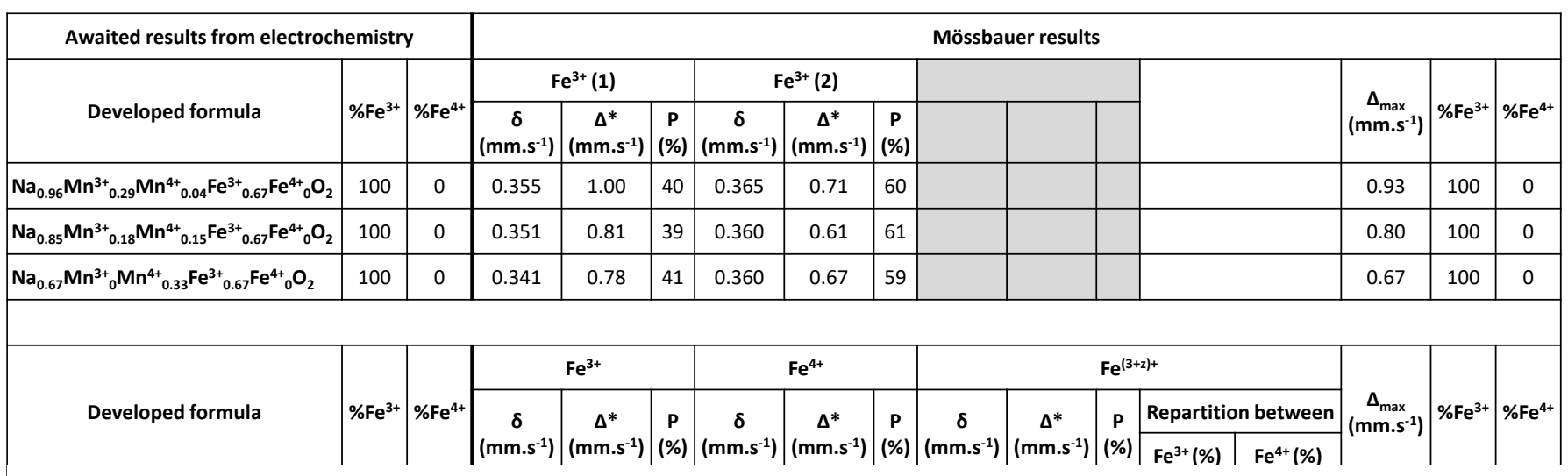

Table 4. Developed formulas, awaited $\mathrm{Fe}^{\mathrm{n}+}$ populations and Mössbauer results corresponding to the in situ Mössbauer experiment presented in Figure 11. The standard deviations on the isomer shift values are equal to $0.002 \mathrm{~mm} . \mathrm{s}^{-1}$. 
fitted using two $\mathrm{Fe}^{3+}$ sites, as for the pristine material. These sites are labelled as $\mathrm{Fe}^{3+}(1)$ and $\mathrm{Fe}^{3+}(2)$ to avoid any confusion with the sites deduced from the Lorentzian fit. The associated signals correspond to doublets whose isomeric shift values, determined during the preliminary Lorentzian refinement, are very close ( $\delta$ $=0.355 \mathrm{~mm} \cdot \mathrm{s}^{-1}$ and $0.365 \mathrm{~mm} \cdot \mathrm{s}^{-1}$ for the $x=0.96$ composition).

The quadrupole splitting values of the two $\mathrm{Fe}^{3+}$ sites corresponding to the $\mathrm{O}^{\prime} 3$ phase $(x=0.96)$ are quite different from each other $\left(\Delta^{*}=1.00 \mathrm{~mm} . \mathrm{s}^{-1}\right.$ and $0.71 \mathrm{~mm} . \mathrm{s}^{-1}$ for the $\mathrm{Fe}^{3+}(1)$ and $\mathrm{Fe}^{3+}(2)$ sites respectively). As the quadrupole splitting is directly correlated to the deformation of the $\mathrm{FeO}_{6}$ site, the high value for the $\mathrm{Fe}^{3+}$ (1) site indicates that it is the most impacted by the cooperative Jahn-Teller effect of the surrounding $\mathrm{Mn}^{3+}$ ions. Moreover, when the structure evolves from O'3 to O3, the quadrupole splitting of the $\mathrm{Fe}^{3+}$ (1) site decreases continuously indicating it is also the most impacted by the $\mathrm{Mn}^{3+} \rightarrow \mathrm{Mn}^{4+}$ redox reaction. In the meantime, the quadrupole splitting associated to the $\mathrm{Fe}^{3+}$ (2) site does not show significant evolution. Therefore, we can conclude that the $\mathrm{Fe}^{3+}$ (1) site corresponds to a local $\mathrm{Fe}$ environment mostly surrounded by $\mathrm{Mn}^{\mathrm{n}+}$ ions (even though there is a distribution of environments) while the $\mathrm{Fe}^{3+}$ (2) site corresponds to a local Fe environment mostly surrounded by other $\mathrm{Fe}^{3+}$ ions (including also a distribution of environments).

The populations of the two sites give an average $\mathrm{Fe}^{3+}(1)$ : $\mathrm{Fe}^{3+}$ (2) ratio of $40: 60$ and is maintained in the $0.96 \geq \mathrm{x} \geq 0.67$ range. In the same $\mathrm{Na}$ range, the isomer shift decreases, upon $\mathrm{Na}^{+}$ deintercalation (from $0.355 \mathrm{~mm} . \mathrm{s}^{-1}$ to $0.341 \mathrm{~mm} . \mathrm{s}^{-1}$ for $\mathrm{Fe}^{3+}$ (1) and from $0.365 \mathrm{~mm} . \mathrm{s}^{-1}$ to $0.360 \mathrm{~mm} . \mathrm{s}^{-1}$ for $\mathrm{Fe}^{3+}$ (2)), in agreement with the increase of the Mn average oxidation state in the nearby $\mathrm{Fe}^{3+}$ ion area.

For lower sodium contents $(\mathrm{x}<0.67)$ all the $\mathrm{Mn}^{3+}$ ions have been oxidized to $\mathrm{Mn}^{4+}$ according to the XANES measurements and the active redox process is now $\mathrm{Fe}^{3+} \rightarrow \mathrm{Fe}^{4+}$. The Mössbauer spectra of the $x=0.58$ and $x=0.38$ phases require three $\mathrm{Fe}^{n+}$ sites to be fitted. The first one shows an isomer shift of $0.336-0.321$ $\mathrm{mm} . \mathrm{s}^{-1}$ (depending on the Na content) and is attributed to HS$\mathrm{Fe}^{3+}$ ions in octahedral environment. The second one is characterized by an isomer shift close to $0 \mathrm{~mm} . \mathrm{s}^{-1}$, typical of the $\mathrm{Fe}^{4+}$ ion in octahedral environment, as also observed in other oxides, in the High $\mathrm{Spin}^{60}$ or Low Spin ${ }^{61,62}$ states. The spin state of tetravalent iron ions in our compounds has not yet been established. The existence of the $\mathrm{Fe}^{3+}$ and $\mathrm{Fe}^{4+}$ sites was predictable, based on the charge compensation in the material and was already investigated in the $\mathrm{Na}_{x} \mathrm{FeO}_{2}$ phase diagram by Takeda et al. ${ }^{52}$ and in the $\mathrm{P} 2-\mathrm{Na}_{x} \mathrm{Mn}_{1 / 2} \mathrm{Fe}_{1 / 2} \mathrm{O}_{2}$ phase ${ }^{12,}{ }^{13}$. Confirming the developed formulae in Table 4, the population of the $\mathrm{Fe}^{4+}$ site increases as the one of the $\mathrm{Fe}^{3+}$ site decreases upon $\mathrm{Na}^{+}$deintercalation.

The third site shows an intermediate isomer shift between $\mathrm{Fe}^{3+}$ and $\mathrm{Fe}^{4+}$. We associated this site to an intermediate $\mathrm{Fe}^{(3+\mathrm{z})+}$ oxidation state that can result from fast electron hopping between the $\mathrm{Fe}^{3+}$ and $\mathrm{Fe}^{4+}$ ions, as already observed in the $\mathrm{Li}_{\mathrm{x}} \mathrm{Ni}_{0.70} \mathrm{Fe}_{0.15} \mathrm{Co}_{0.15} \mathrm{O}_{2}$ system ${ }^{60}$ and in the $\mathrm{Ni}_{1-\mathrm{y}} \mathrm{Fe}_{\mathrm{y}} \mathrm{OOH}_{\mathrm{x}} / \mathrm{Ni}_{1-}$ ${ }_{y} \mathrm{Fe}_{y}(\mathrm{OH})_{2}$ one, both ex ${ }^{61}$ and in situ ${ }^{62}$. This intermediate $\mathrm{Fe}^{(3+\mathrm{z})+}$ oxidation state can be separated into the $\mathrm{Fe}^{3+}$ and $\mathrm{Fe}^{4+}$ ones considering that the sum of the populations of the involved $\mathrm{Fe}^{3+}$ and $\mathrm{Fe}^{4+}$ sites is equal to 1.0 and using the following formula: $\mathrm{P}\left(\mathrm{Fe}^{3+}\right)=\left(\delta\left(\mathrm{Fe}^{3+\mathrm{z}}\right)-\delta\left(\mathrm{Fe}^{4+}\right)\right) /\left(\delta\left(\mathrm{Fe}^{3+}\right)-\delta\left(\mathrm{Fe}^{4+}\right)\right)$, where $\mathrm{P}\left(\mathrm{Fe}^{3+}\right)$ is the population of the involved $\mathrm{Fe}^{3+}$ ions. The repartition of the population of the $\mathrm{Fe}^{(3+\mathrm{z})+}$ site into the $\mathrm{Fe}^{3+}$ and $\mathrm{Fe}^{4+}$ ones is given in Table 4. We observe good agreement between the material compositions deduced from the Mössbauer data $\left(\mathrm{Na}_{0.58} \mathrm{Mn}_{1 / 3} \mathrm{Fe}_{2 / 3} \mathrm{O}_{2}\right.$ and $\left.\mathrm{Na}_{0.40} \mathrm{Mn}_{1 / 3} \mathrm{Fe}_{2 / 3} \mathrm{O}_{2}\right)$ and the ones deduced by electrochemistry (Na0.58 $\mathrm{Mn}_{1 / 3} \mathrm{Fe}_{2 / 3} \mathrm{O}_{2}$ and $\mathrm{Na}_{0.38} \mathrm{Mn}_{1 / 3} \mathrm{Fe}_{2 / 3} \mathrm{O}_{2}$, respectively).

Furthermore, the quadrupole splitting values between the two samples increase significantly as $\mathrm{Na}^{+}$is removed from the system, and especially for the $\mathrm{Fe}^{4+}$ site $\left(\Delta^{*}=0.19 \mathrm{~mm} \cdot \mathrm{s}^{-1}\right.$ and $0.55 \mathrm{~mm} . \mathrm{s}^{-1}$ for the $x=0.58$ and $x=0.38$ compositions, respectively), indicating an increasing disorder inside the material from $x=0.58$ to $x=0.38$. This statement is in agreement with the in situ XRPD results which showed the coexistence of two phases: P3 (majority) and O3-O1* (minority).

The Mössbauer results obtained on the $\mathrm{Na}_{x} \mathrm{Mn}_{1 / 3} \mathrm{Fe}_{2 / 3} \mathrm{O}_{2}$ system show that the $\mathrm{Mn}^{4+/ 3+}$ and $\mathrm{Fe}^{4+/ 3+}$ redox couples are successively involved during the electrochemical deintercalation in agreement with the electrochemical results which show a sudden voltage increase for $x=2 / 3$.

\section{Conclusions}

$\mathrm{O} 3-\mathrm{Na}_{x} \mathrm{Mn}_{1 / 3} \mathrm{Fe}_{2 / 3} \mathrm{O}_{2}(x=0.77)$ prepared by self-combustion synthesis was further investigated in this work. The Rietveld refinement of the structure from the synchrotron XRPD pattern does not show any evidence of the occurrence of transition metal vacancies that we previously suspected ${ }^{14}$. Furthermore, the neutron diffraction pattern does not highlight any long-range ordering between the $\mathrm{Mn}$ and Fe elements, despite the $1: 2$ ratio between these species. The electrochemical tests carried out in the $1.5-3.8 \mathrm{~V}, 1.5-4.0 \mathrm{~V}$ and $1.5-4.3 \mathrm{~V}$ ranges show that all cells reached the same capacity after 14 cycles whatever the initial values.

The operando in situ XRPD experiment highlights several structural transitions upon $\mathrm{Na}^{+}$deintercalation from the fully intercalated phase. In its maximum state of intercalation the material exhibit a monoclinic distortion (O'3 phase) due to the presence of Jahn-Teller effect of $\mathrm{Mn}^{3+}$ ions, even if only $33 \%$ of $\mathrm{Mn}^{3+}$ ions are present in the slabs. Further deintercalation leads to the $\mathrm{O} 3$ structure followed by the P3 one. Nevertheless, a part of the $\mathrm{O} 3$ phase is not transformed into P3 upon sodium deintercalation. This suggests the existence of an inhomogeneity in the pristine material (Fe/Mn) which is not detected by XRPD. For lower intercalation contents an "X" phase of unknown structure is observed. The presence of remaining diffraction peaks between the O3, P3 and "X" structural domains seems to indicate that the $\mathrm{O} 3 / \mathrm{P} 3 \rightarrow$ " $\mathrm{X}$ " structural transition is achieved through the apparition of stacking faults. It is possible that the numerous structural transitions are correlated to the decrease of the capacity retention observed when the material is cycled above $3.8 \mathrm{~V}$. However, more experiments are needed before we can conclude on this topic. 
The XANES and ${ }^{57} \mathrm{Fe}$ Mössbauer spectroscopy results confirm that the $\mathrm{Mn}^{4+} / \mathrm{Mn}^{3+}$ redox couple is active at low voltage and that the $\mathrm{Fe}^{4+} / \mathrm{Fe}^{3+}$ one is active at high voltage. A $\mathrm{Fe}^{(3+\mathrm{z})+}$ state of the iron ions is also highlighted at high voltage. It is believed to result from fast electron hopping between the $\mathrm{Fe}^{3+}$ and $\mathrm{Fe}^{4+}$ ions. ${ }^{57} \mathrm{Fe}$ Mössbauer spectroscopy also evidences an increasing disorder in the material upon $\mathrm{Na}^{+}$deintercalation that could be induced by the existence of the remaining phases.

\section{Acknowledgements}

This work beneficiated from a grant from Agence Nationale de la Recherche (Blanc Inter II, SIMI 8) $\mathrm{n}^{\circ}$ 2011-IS08-01. Region Aquitaine and CNRS are also acknowledged for B.M. scholarship. The authors also thank ILL (Grenoble, France) for the beam time granted on the $\mathrm{D} 2 \mathrm{~B}$ high-resolution neutron diffractometer. We acknowledge the European Synchrotron Radiation Facility for provision of synchrotron radiation facilities and we would like to thank Dr. C. Drathen for assistance in using beamline ID31 (now ID22).

\section{Notes and references}

${ }^{a}$ CNRS, Université de Bordeaux, ICMCB, 33608 Pessac Cedex, France.

${ }^{b}$ Department of Chemical Engineering, National Taiwan University of Science and Technology (NTUST), Taipei 106, Taiwan.

${ }^{c}$ Chemistry Department, Lomonosov Moscow State University, Moscow 119991, Russia.

${ }^{d}$ ESRF, 6 rue Jules Horowitz BP 220, 38043 Grenoble, France.

${ }^{e}$ Institut Laue-Langevin, 71 Avenue des Martyrs, F-38000 Grenoble, France.

${ }^{f}$ National Synchrotron Radiation Research Center (NSRRC), Hsinchu 30076, Taiwan.

$\dagger$ Electronic Supplementary Information (ESI) available: Combined refinement of " $\mathrm{O} 3-\mathrm{Na}_{0.82} \mathrm{Mn}_{1 / 3} \mathrm{Fe}_{2 / 3} \mathrm{O}_{2}$ " (Rietveld method) based on neutron powder diffraction and XRPD patterns, galvanostatic cycling curve with the electrolyte using $2 \mathrm{wt} \% \mathrm{VC}$ additive, inversed representation of the operando in situ experiment, XRPD patterns recorded in situ during the relaxation of a $\mathrm{Na}_{x} \mathrm{Mn}_{1 / 3} \mathrm{Fe}_{2 / 3} \mathrm{O}_{2} / / \mathrm{Na}$ cell, magnification of the operando in situ XRPD experiment in the $0.1<\mathrm{x}<0.7$ region and superposition of the ${ }^{57} \mathrm{Fe}$ Mössbauer spectra. See DOI: 10.1039/b000000x/

1. C. Delmas, J.-J. Braconnier, C. Fouassier and P. Hagenmuller, Solid State Ionics, 1981, 3/4, 165 - 169.

2. J.-J. Braconnier, C. Delmas and P. Hagenmuller, Mater. Res. Bull., 1982, 17, $993-1000$.

3. A. Maazaz, C. Delmas and P. Hagenmuller, C. R. Acad. Sci. Paris, $1982,295,759-760$.

4. A. Maazaz, C. Delmas and P. Hagenmuller, J. Incl. Phenom., 1983, 1, $45-51$.

5. J. M. Tarascon and G. W. Hull, Solid State Ionics, 1986, 22, 85 - 96.

6. X. Ma, H. Chen and G. Ceder, J. Electrochem. Soc., 2011, 158, A1307 - A1312.

7. S.-Y. Yang, X.-Y. Wang, Y. Wang, Q.-Q. Chen, J.-j. Li and X.-K. Yang, T. Nonferr. metal. Soc., 2010, 20, 1892 - 1898.

8. D. Su, C. Wang, H. J. Ahn and G. Wang, Chemistry, 2013, 19, 10884 $-10889$.

9. N. Yabuuchi, H. Yoshida and S. Komaba, Electrochemistry, 2012, 80, $716-719$.
10. J. Zhao, L. Zhao, N. Dimov, S. Okada and T. Nishida, J. Electrochem. Soc., 2013, 160, A3077 - A3081.

11. B. Mortemard de Boisse, D. Carlier, M. Guignard, L. Bourgeois and C. Delmas, Inorg. Chem., 2014, 53, 11197 - 11205.

12. N. Yabuuchi, M. Kajiyama, J. Iwatate, H. Nishikawa, S. Hitomi, R. Okuyama, R. Usui, Y. Yamada and S. Komaba, Nat. Mat., 2012, 11,512 - 517.

13. J. S. Thorne, R. A. Dunlap and M. N. Obrovac, J. Electrochem. Soc., 2012, 160, A361 - A367.

14. B. Mortemard de Boisse, D. Carlier, M. Guignard and C. Delmas, J. Electrochem. Soc., 2013, 160, A569 - A574.

15. G. Singh, B. Acebedo, M. C. Cabanas, D. Shanmukaraj, M. Armand and T. Rojo, Electrochem. Comm., 2013, 37, 61 - 63.

16. T. Kodera and T. Ogihara, J. Ceram. Soc. Jpn, 2014, 122, 483 - 487.

17. K. Park, D. Han, H. Kim, W.-s. Chang, B. Choi, B. Anass and S. Lee, R. Soc. Chem. Adv., 2014, 4, 22798 - 22802.

18. J. Zhao, J. Xu, D. H. Lee, N. Dimov, Y. S. Meng and S. Okada, J. Power Sources, 2014, 264, 235 - 239.

19. H. Zhu, K. T. Lee, G. T. Hitz, X. Han, Y. Li, J. Wan, S. Lacey, A. Cresce, K. Xu, E. Wachsman and L. Hu, ACS Appl. Mater. Interfaces, 2014, 6, 4242 - 4247.

20. E. Gonzalo, M. H. Han, J. M. Lopez del Amo, B. Acebedo, M. CasasCabanas and T. Rojo, J. Mater. Chem. A, 2014, 2, 18523 18530.

21. Z. Lu and J. R. Dahn, J. Electrochem. Soc., 2001, 148, A1225 - A1229.

22. S. Komaba, N. Yabuuchi, T. Nakayama, A. Ogata, T. Ishikawa and I. Nakai, Inorg. Chem., 2012, 51, 6211 - 6220.

23. X. Xia and J. R. Dahn, J. Electrochem. Soc., 2012, 159, A1048 A1051.

24. H. Wang, B. Yang, X.-Z. Liao, J. Xu, D. Yang, Y.-S. He and Z.-F. Ma, Electrochim. Acta, 2013, 113, 200 - 204.

25. G. Liu, L. Wen, Y. Li and Y. Kou, Ionics, 2014, DOI: 10.1007/s11581014-1249-2.

26. Y. Zhang, K. Ye, K. Cheng, G. Wang and D. Cao, Electrochim. Acta, 2014, 148, 195 - 202.

27. W. Zhao, H. Kirie, A. Tanaka, M. Unno, S. Yamamoto and H. Noguchi, Materials Letters, 2014, 135, 131 - 134.

28. N. Yabuuchi, R. Hara, K. Kubota, J. Paulsen, S. Kumakura and S. Komaba, J. Mater. Chem. A, 2014, 2, 16851 - 16855.

29. X. Wang, G. Liu, T. Iwao, M. Okubo and A. Yamada, J. Phys. Chem. C, 2014, 118, 2970 - 2976.

30. D. Kim, E. Lee, M. Slater, W. Lu, S. Rood and C. S. Johnson, Electrochem. Comm., 2012, 18, 66 - 69.

31. N. Yabuuchi, M. Yano, H. Yoshida, S. Kuze and S. Komaba, J. Electrochem. Soc., 2013, 160, A3131 - A3137.

32. Z. Lu and J. R. Dahn, Chem. Mater., 2001, 13, 1252 - 1257.

33. M. Sathiya, K. Hemalatha, K. Ramesha, J. M. Tarascon and A. S. Prakash, Chem. Mater., 2012, 24, 1846 - 1853.

34. D. Buchholz, A. Moretti, R. Kloepsch, S. Nowak, V. Siozios, M. Winter and S. Passerini, Chem. Mater., 2013, 25, 142 - 148.

35. D. Yuan, W. He, F. Pei, F. Wu, Y. Wu, J. Qian, Y. Cao, X. Ai and H. Yang, J. Mater. Chem. A, 2013, 1, 3895 - 3899.

36. L. G. Chagas, D. Buchholz, L. Wu, B. Vortmann and S. Passerini, J. Power Sources, 2014, 247, 377 - 383.

37. S. Doubaji, M. Valvo, I. Saadoune, M. Dahbi and K. Edström, J. Power Sources, 2014, 266, 275 - 281. 
38. J. Yoshida, E. Guerin, M. Arnault, C. Constantin, B. Mortemard de Boisse, D. Carlier, M. Guignard and C. Delmas, J. Electrochem. Soc., 2014, 161, A1987 - A1991.

39. D. Yuan, X. Hu, J. Qian, F. Pei, F. Wu, R. Mao, X. Ai, H. Yang and Y. Cao, Electrochim. Acta, 2014, 116, 300 - 305.

40. C. Delmas, C. Fouassier and P. Hagenmuller, Phys. 99B, 1980, 81 85.

41. V. Petricek, M. Dusek and L. Palatinus, Z. Kristallogr., 2014, 229, 345 $-352$.

42. S. Komaba, T. Ishikawa, N. Yabuuchi, W. Murata, A. Ito and Y. Ohsawa, ACS Appl. Mater. Interfaces, 2011, 3, 4165 - 4168.

43. J. B. Leriche, S. Hamelet, J. Shu, M. Morcrette, C. Masquelier, G. Ouvrard, M. Zerrouki, P. Soudan, S. Belin, E. Elkaïm and F. Baudelet, J. Electrochem. Soc., 2010, 157, A606 - A610.

44. J.-P. Parant, R. Olazcuaga, M. Devalette, C. Fouassier and P. Hagenmuller, J. Solid State Chem., 1971, 3, 1 - 11.

45. R. Stoyanova, D. Carlier, M. Sendova-Vassileva, M. Yoncheva, E. Zhecheva, D. Nihtianova and C. Delmas, J. Solid State Chem., 2010, 183, 1372 - 1379.

46. L. Bordet-Le Guenne, P. Deniard, P. Biensan, C. Siret and R. Breca, J. Mater. Chem., 2000, 10, 2201 - 2206.

47. D. Carlier, J. H. Cheng, R. Berthelot, M. Guignard, M. Yoncheva, R. Stoyanova, B. J. Hwang and C. Delmas, Dalton. T., 2011, 40, 9306 - 9312.

48. C. Pouillerie, L. Croguennec and C. Delmas, Solid State Ionics, 2000, $132,15-29$.

49. L. Seguin, G. Amatucci, M. Anne, Y. Chabre, P. Strobel, J. M. Tarascon and G. Vaughan, J. Power Sources, 1999, 81-82, 604 $-606$.

50. L. Croguennec, C. Pouillerie and C. Delmas, J. Electrochem. Soc., 2000, 147, 1314 - 1321.

51. J. Xu, D. H. Lee, R. J. Clément, X. Yu, M. Leskes, A. J. Pell, G. Pintacuda, X.-Q. Yang, C. P. Grey and Y. S. Meng, Chem. Mater., 2014, 26, 1260 - 1269.

52. Y. Takeda, K. Nakahara, M. Nishijima, N. Imanishi, O. Yamamoto, M. Takano and R. Kanno, Mater. Res. Bull., 1994, 29, 659 - 666.

53. J. P. Peres, C. Delmas, A. Rougier, M. Broussely, F. Perton, P. Biensan and P. Willmann, J. Phys. Chem. Solids, 1996, 57, 1057-1060.

54. P. W. Stephens, J. Appl. Crystallogr., 1999, 32, 281 - 289.

55. C. Delmas and C. Tessier, J. Mater. Chem., 1997, 7, 1439 - 1443.

56. L. D. Dyer, B. S. Borie and G. P. Smith, J. Am. Chem. Soc., 1954, 76, 1499.

57. C. Didier, M. Guignard, C. Denage, O. Szajwaj, S. Ito, I. Saadoune, J. Darriet and C. Delmas, Electrochem. Solid. St., 2011, 14, A75 A78.

58. R. Berthelot, D. Carlier and C. Delmas, Nat. Mat., 2011, 10, 74 - 80.

59. M. Guignard, C. Didier, J. Darriet, P. Bordet, E. Elkaïm and C. Delmas, Nat. Mat., 2013, 12, 74 - 80.

60. G. Prado, L. Fournès and C. Delmas, J. Solid State Chem., 2001, 159, $103-112$.

61. L. Demourgues-Guerlou, L. Fournès and C. Delmas, J. Solid State Chem., 1995, 114, 6 - 14.

62. L. Guerlou-Demourgues, L. Fournès and C. Delmas, J. Electrochem. Soc., 1996, 143, 3083 - 3088. 